\title{
DAS PRIMEIRAS LEIS DE PROTECÇÃO DA INFÂNCIA E JUVENTUDE, EM PORTUGAL, À ENTRADA EM VIGOR DA L.P.C.J.P.
}

Cláudia Sofia Antunes Martins

ÍNDICE

1. Nota prévia

2. A Lei de Protecção à Infância

2.1. Finalidade

2.2. Âmbito de aplicação

2.3. Apreciação crítica ao regime da L.P.I.

3. A Organização Tutelar de Menores

3.1. Finalidade e âmbito de aplicação

3.2. A primeira alteração à O.T.M.

3.3. A segunda alteração à 0.T.M

3.4. Apreciação crítica ao regime da 0.TM.

4. A Lei de Protecção de Crianças e Jovens em Perigo

4.1. Objectivos e âmbito de aplicação

4.2. Entidades com legitimidade de intervenção

4.3. Princípios fundamentais

4.4. Medidas de promoção e protecção

5. Notas finais

PRINCIPAIS ABREVIATURAS

REFERÊNCIAS BIBLIOGRÁFICAS

\section{NOTA PRÉVIA}

Portugal foi um dos países pioneiros, na Europa, a adoptar, no início do século XX, um diploma legal específico em matéria de infância e juventude, a Lei da Protecção à Infância ${ }^{1}$.

Como se sublinhava no preâmbulo do citado diploma, há muito que se fazia sentir a necessidade de uma intervenção mais activa e profiláctica do Estado 
numa área do direito que até então nunca havia despertado "a attenção das leis que nos teem regido". Reconhecendo que a criança constituía a "base das sociedades, a matéria prima com que hão-de construir-se e comentar-se os alicerces, erguer-se a architectura desempenada de uma nacionalidade", e que "da criança dae o homem", era preciso assumir como preocupação profícua da política nacional cuidar da criança desprovida, furtando-a "aos ambientes viciadas", de modo a que, através de uma intervenção estadual precoce, protegendo-a, quando se encontrasse em perigo moral, e regenerando-a através da educação, quando desse sinais de se encontrar corrompida, ela pudesse resvalar no crime.

Constituía, assim, um imperativo basilar do Estado organizar a jurisdição de menores sob um novo espírito, menos repressivo, especializando o direito penal e processual aplicável as crianças e jovens. Simultaneamente, a acção protectora não podia limitar-se às obras e instituições de caridade, devendo adquirir uma faceta mais complexa que reunisse simultaneamente uma vertente assistencial, educacional e judicial.

A L.P.I. introduziu, assim, um quadro normativo que simultaneamente previa medidas de amparo a crianças e jovens em situação de perigo moral e medidas reeducativas dirigidas a jovens qualificados de delinquentes, para-delinquentes ou incorrigíveis ${ }^{3}$ (distintas das aplicáveis aos adultos), em tribunais de competência especializada.

0 citado diploma, após uma fase experimental, em que só vigorou na região de Lisboa, grande Porto e Coimbra ${ }^{4}$, em 1925, estendeu a sua eficácia a todo o território nacional ${ }^{5}$, tendo vindo, ao longo dos anos, a sofrer consecutivas reformulações ${ }^{6}$.

\section{${ }^{2}$ Cf. Preâmbulo da L.P.I.}

${ }^{3}$ Tendo ainda feito referência aos menores portadores de doença mental [art. $73^{\circ}$ a $76^{\circ}$ da L.P.I.].

${ }^{4} \mathrm{Cf}$ art. $1^{\circ}$ da Lei de 24 de Abril de 1912 e art. $1^{\circ}$ do Dec.-Lei $n^{0}$ ?22, de 4 de Agosto de 1914.

${ }^{5}$ Com a publicação do Dec.-Lei no 10 76?, de 15 de Maio.

${ }^{6}$ Introduziram modificações na L.P.I. os seguintes diplomas: a Lei de 24 de Abril de 1912; o Dec. -Lei n 722, de 4 de Agosto de 1914; o Dec.-Lei no 897, de 29 de Setembro de 1914; a Lei no 540 de 19 de Maio de 1916; a Lei no 683, de 12 de Maio de 1917; o Dec.-Lei no 3 987, de 23 de Maio de 1918; o Dec.-Lei no 4 681, de 9 de Julho de 1918; o Dec.-Lei nº 5611 de 10 de Maio de 1919; 0 Dec.-Lei ${ }^{0} 5$ 954, de 12 de Julho de 1919; o Dec.-Lein ${ }^{0} 6$ 11? de 20 de Setembro de 1919; o Dec. Lei no 6 639, de 27 de Maio de 1920; o Dec.-Lei no 9 152, de 27 de Setembro de 1923; o Dec.-Lei $n^{0} 10767$ de 15 de Maio de 1925; o Dec.-Lei no 12 544, de 22 de Outubro de 1926; o Dec.-Lei no 12 686, de 16 de Novembro de 1826; o Dec.-Lei no 15 162, de 15 de Março de 1928; o Dec.-Lei no 15 344, de 12 de Abril de 1928; o Dec.-Lei no 17 955, de 12 de Fevereiro de 1930; os Dec.-Lei ${ }^{\circ}$ 18 996, de 1 de Novembro de 1930, e o Dec.-Lei ${ }^{0} 19230$ de 10 de Janeiro de 1931 revogados pelo Dec.-Lei nº 20 431, de 24 de Outubro de 1931; o Dec.-Lei n 22 708, de 20 de Junho de 1933;
Na segunda metade do século, teve lugar a segunda grande reforma interna em matéria de protecção de menores com a entrada em vigor, em 1962, da Organização Tutelar de Menores (que revogou a L.P.I.), de matriz acentuadamente proteccionista, que passou a equiparar, para efeitos de enquadramento legal e medidas adoptadas, os designados menores em perigo moral e os menores delinquentes.

Neste diploma, sai reforçado o papel do Estado na tríplice função de "proteger, assistir e educar" as crianças e os jovens. Aquele passa a ter legitimidade para intervir, através dos seus órgãos judiciais, sempre que sinalizada uma situação de "menor-problema considerado carecido de protecção"? como um bom pater familias.

A O.T.M. sofreu pequenas alterações, em 1967, sendo, mais tarde, revista, em 1978, com o objectivo de introduzir novas formas de participação da comunidade na administração da justiça, harmonizando-se com as novas disposições em matéria de organização dos tribunais judiciais ${ }^{8}$.

A terceira e mais importante reforma do nosso ordenamento jurídico de protecção da infância e juventude teve lugar, no final do século XX, com a publicação, em 1999, da Lei de Protecção das Crianças e Jovens e da Lei Tutelar Educativa, as quais entraram em vigor a 1 de Janeiro de 2001.

É à luz do primeiro dos citados diplomas, a L.P.C.J.P., que passamos a encontrar o regime jurídico actual em matéria de protecção das crianças e jovens em situação de perigo e promoção dos seus direitos fundamentais.

Neste trabalho, procurar-se-á, assim, analisar os principais traços caracterizadores do quadro legal de protecção da infância e juventude, em Portugal, em cada uma das três etapas temporais em que ele se divide (L.P.I, O.T.M. e L.P.C.J.P.) de modo a que, através de uma visão de conjunto se compreenda melhor as importantes mutações introduzidas numa área do direito que só há pouco tempo mereceu o merecido interesse e destaque dos juristas.

o Dec.-Lei no 31 189, de 24 de Março de 1941; o Dec.-Lei no 33 547, de 23 de Abril de 1944; 0 Dec.-Lei no 35 955, de 19 de Novembro de 1946; o Dec.-Lei no 38 386, de 8 de Agosto de 1951; a Lei no 2 053, de 22 de Março de 1952; o Dec.-Lei no 38 964, de 27 de Outubro de 1952; o Dec-Lei $n^{0} 39$ 688, de 5 de Junho de 1954; o Decreto n 40 87?, de 24 de Novembro de 1956; o Dec.-Lei $n^{\circ} 41$ 051, de 1 de Abril de 1957; e o Dec-Lei no 42 660, de 20 de Novembro de 1959. Vide ainda EURICO SERRA, Os tribunais de menores e a sua jurisdição, in "Separata do Boletim do Ministério da Justiça", 103 (1961), pp. 17-32

${ }^{2}$ Cf. RUI ASSIZ, A Intervenção do Estado no Domínio das Crianças e Jovens em Perigo, in "Scientia luridica", T.L., 289, Janeiro/Abril (2001), pp. 157-158.

${ }^{8}$ Cf. Lei n ${ }^{\circ} 82 / 77$, de 6 de Dezembro e art. $202^{\circ}, n^{\circ} 4$ da C.R.P. 


\section{A LEI DE PROTECÇÃO À INFÂNCIA}

\subsection{FINALIDADE}

Visava o legislador, com a L.P.I., "prevenir os males sociais" que pudessem conduzir à perversão, ao crime ou ao comprometimento da vida ou saúde das crianças e jovens, com idade inferior a dezasseis anos, de ambos os sexos, e curar os seus efeitos ${ }^{9}$. A intervenção protectora das tutorias estendeu-se, a partir de 1928, a qualquer criança ou jovem, com idade inferior a vinte um $\operatorname{anos}^{10}$, com excepção dos jovens agentes de factos qualificados como crimes pela lei penal, os quais só ficariam sujeitos à sua intervenção tutelar se ainda não houvessem completado os dezasseis anos ${ }^{11}$.

Criou, ainda, os primeiros tribunais especializados em direito dos menores, as tutorias de infância, tribunais colectivos que julgavam segundo o critério da equidade e segundo o juízo de um "bom pae de família", de forma justa e sempre tendo em atenção o interesse dos menores. Compreendia-se já que as questões em matéria de menores e família não podiam ser decididas segundo "o rigor formulário de uma legislação taxativa" e formal, mas de acordo com regras de equidade adequadas às circunstâncias concretas de cada caso ${ }^{12}$. Visou-se ainda dar uma natureza subjectiva à jurisdição de menores, com o estudo individualizado do menor. Nesse sentido, foram criadas três tutorias centrais da infância, em Lisboa, Porto e Coimbra, e várias tutorias comarcãs, nas remanescentes comarcas ${ }^{13}$.

\section{${ }^{9}$ Cf. art. $1^{0}$ da L.P.I.}

${ }^{10} \mathrm{Cf}$. art. $27^{\circ}$ do Decreto $\mathrm{n}^{0} 15$ 162, de 10 de Março de 1928.

${ }^{11} 0$ Decreto no 10 76?, de 15 de Maio de 1925 admitiu, todavia, não só a aplicação de medidas de correcção, designadamente, o internamento em Colónia correccional, a jovens com mais de dezasseis anos, se condenados nos tribunais comuns a pena maior ou correccional superior a seis meses e se o Conselho Penal e Prisional assim o entendesse; como o julgamento, nos tribunais comuns, de jovens que, à data da prática do facto criminoso, tivessem idade inferior a dezasseis anos, se, quando presentes ao juiz, já houvessem completado os dezasseis anos [arts. $32^{\circ} \mathrm{e}$ $\left.108^{\circ}, \S 2^{\circ}\right]$. Quando os jovens completavam os dezoito anos, com seis anos de internato, ou os vinte e um anos, se fossem considerados não regenerados pelas tutorias, eram colocados por sentença à disposição do Governo [art. $81^{\circ}$, § único da L.P.I.], podendo determinar-se o seu alistamento, voluntário ou coercivo, no exército na marinha ou nas forças armadas e o seu envio para as colónias ou para o estrangeiro [arts. $30^{\circ}$, alínea a] e b] e $112^{\circ}$ do Decreto no 10767 , de 15 de Maio de 1925].

${ }^{12}$ Cf. art. $2^{\circ}, \S 2$ da L.P.I.

${ }^{13}$ As tutorias comarcãs só entraram em funcionamento em todo o território nacional, em 1925 , com a publicação do Decreto nº 10 76?, de 15 de Maio de 1925.
Foram ainda instituídos novos estabelecimentos de detenção preventiva de menores junto de cada tutoria central ou comarcã, designados de Refúgios. Estas instituições eram direccionadas para o internamento temporário e observação de crianças e jovens qualificados de maltratados, com idade compreendida entre os sete e os catorze anos, ou de desamparados/delinquentes, com idade inferior a dezasseis anos ${ }^{14}$. Estes estabelecimentos visavam ser locais de simples passagem, enquanto as crianças ou jovens não eram entregues a estabelecimentos de assistência ou de correcção, porém a realidade mostrava como acabavam por aí permanecer por longos períodos enquanto aguardavam vaga na respectiva instituição. Nos refúgios, apenas os jovens delinquentes, desamparados ou indisciplinados, eram objecto de observação e análise com o objectivo precípuo de conhecer a sua história pessoal e familiar e a sua personalidade e, assim, determinar a medida mais adequada a ser-Ihes aplicada ${ }^{15}$.

\section{2. ÂMBITO DE APLICAÇÃO}

2.2.2. As crianças e jovens abrangidas pela acção tutelar

A L.P.I. dirigiu a sua intervenção protectora/educativa aos menores que qualificou: a) em perigo moral ( a quem poderiam ser aplicadas medidas de tutela e de protecção ${ }^{16}$ ); b) desamparados (passíveis de medidas de protecção ou de correcção ${ }^{17}$ ); c] delinquentes ( submetendo-os a um processo específico paralelo ao processo penal dos adultos e a medidas de prevenção, preservação e correcção, de acordo com regras e princípios jurídicos penais diferentes dos do processo penal dos adultos ${ }^{18}$ ); d) indisciplinados (sujeitos a medidas reeducativas

${ }^{14}$ Cf. arts. $108^{\circ} ; 109^{\circ}$; e $136^{\circ}$, da L.P.I.

${ }_{15}$ Mais tarde, o Dec.-Lei no 10 ?6?, de 15 de Maio de 1925, virá especificar que, em cada refúgio, deveria haver um posto para realização de exames antropológicos, médicos e pedagógicos aos menores delinquentes e para-delinquentes, assim como, inquéritos às suas condições sociais e familiares e estudos às suas aptidões profissionais. Os refúgios foram concebidos de modo a preverem divisões separadas para raparigas e para rapazes e, em cada divisão, várias secções, onde os menores eram apartados em função do seu estado de desenvolvimento e perversão [art. $102^{\circ}$ do Decreto no 10 76?, de 15 de Maio de 1925 e art. $133^{\circ}$ e seu §̧ único da L.P.I.]. Com a entrada em vigor da L.P.l., são ainda reformuladas, a nível estrutural e funcional, as antigas Casas de Detenção e Correcção de Lisboa e do Porto, que passam a ser designadas de Escolas de Reforma [art. $144^{\circ}$ da L.P.I.].

${ }^{16}$ Cf. arts. $26^{\circ}$ a $57^{\circ}$ da L.P.I.

${ }^{17}$ Cf. arts. $58^{\circ}$ a $61^{\circ}$ da L.P.I.

${ }^{18} \mathrm{Cf}$. arts. $62^{\circ}$ a $68^{\circ}$ da L.P.I. As crianças consideradas desamparados e delinquentes, com idade inferior a nove anos de idade, em relação às quais se concluísse carecerem de assistência 
e de protecçã $0^{19}$ ); e) e anormais patológicos (remetendo-os para instituições federadas específicas onde lhes era conferido tratamento específico ${ }^{20}$ ).

\subsubsection{Os menores em perigo moral}

0 legislador elencou, de forma taxativa, as situações em que se poderia qualificar uma criança ou jovem em situação de perigo moral para efeitos do preceituado na L.P.I., subsumindo-os a três categorias fundamentais: os menores abandonados ${ }^{21}$; os menores pobres ${ }^{22}$; e os menores maltratados ${ }^{23}$.

(por terem chegado àquela situação em virtude de abandono ou de uma conduta negligente ou maltratante dos seus pais ou tutor], poderiam ficar sujeitas a medidas de protecção, sendo integradas em instituições de assistência, nos termos do art. $76^{\circ}$ da L.P.I.

${ }^{19}$ Cf. arts. $69^{\circ}$ a $72^{\circ}$ da L.P.I.

${ }^{20} \mathrm{Cf}$. arts. $73^{\circ}$ a $75^{\circ} \mathrm{da} \mathrm{L.P.I.}$

${ }^{21}$ Eram considerados menores abandonados: os órfãos ou as crianças cujos pais fossem desconhecidos ou se encontrassem desaparecidos, presos ou doentes, não tendo tutor, familia ou pessoa amiga que aceitasse cuidar deles, nem domicílio certo e meios de subsistência. Cf. arts. $28^{\circ}$ a $38^{\circ}$ da L.P.I. Uma vez sinalizada uma situação de menor abandonado junto de uma tutoria, este apenas poderia vir a ser reclamado e entregue aos seus pais ou tutores desaparecidos depois de verificados certos requisitos: tinham aqueles que fazer prova da sua legítima paternidade, de que o abandono havia sido motivado por circunstâncias alheias à sua vontade e que o menor não se encontrava em perigo moral, nos termos do art. $26^{\circ}, n^{0} \mathrm{~s} 4,5$ e 6 da L.P.I. Caso o juiz decidisse pela entrega do menor aos pais ou tutores, podia ainda fixar um período de vigilância ou condená-los a pagar uma indemnização à instituição que o houvesse acolhido. No caso de o menor abandonado não ser reclamado, no prazo de três meses (ou de seis meses se os seus pais estivessem doentes ou presos], o juiz colocaria-o "sob a guarda e defesa da República", sendo inserido numa instituição particular federada ou de assistência [arts. $31^{\circ}$, § único e $32^{\circ}$ da L.P.I.].

${ }^{22}$ À luz da L.P.I., os menores pobres incluíam apenas as crianças com idade inferior a doze anos cujos pais ou tutores fossem reconhecidos como incapazes ou impotentes para cumprirem os seus deveres paternos ou tutelares, em virtude da sua pobreza ou de uma deficiência física ou mental, não tendo aquele nenhum outro parente ou amigo que aceitasse tomá-lo a seu cuidado [arts. $24^{\circ}$ e seu $\S 1,2$ e $3,26^{\circ}, 39^{\circ}$ e $40^{\circ}$ da L.P.I.]. Uma vez qualificada a situação de pobreza, podia o juiz determinar a inibição dos poderes de guarda, educação e correcção dos progenitores ou tutores do menor, com extensão, ou não, a todos os seus filhos ou pupilos, se se encontrassem preenchidos os seguintes requisitos legais: os progenitores ou tutor declarassem não se oporem à inibição; se se comprovasse o seu estado de pobreza e de honestidade, assim como, que esse estado os impossibilitava de educar devidamente o menor, sendo absolutamente necessária a saída de casa deles; e que o menor não havia sido considerado desamparado nem delinquente. Se reunidos os referidos pressupostos, o juiz podia entregar o menor "sobre protecção da República", ao abrigo do art. $79^{\circ}$ da L.P.I., a instituições de assistência ou federadas com vista à sua entrega em casa de famílias adoptivas ou em estabelecimentos de educação de carácter preventivo.

${ }^{23}$ Os menores maltratados eram sinalizados em função do comportamento dos seus pais ou
Em suma, tal como se enunciava na Portaria $n^{0} 4$ 882, de 6 de Maio de 1927, os menores em perigo moral eram percepcionados como "elementos em si moralmente sãos, mas em risco de perversão pela acção nociva do meio social e familiar que os rodeia e em que vivem, por abandono ou por extrema miséria, quer material, quer moral, etc., estando compreendidos nesta categoria os menores de nove anos, embora tenham praticado actos considerados crimes ou infracções". A protecção que se Ihes dirigia dependia de estes serem declarados em perigo por sentença, restringindo-se a colocarem-nos em regime de liberdade vigiada, sob caução, em instituições federadas para serem entregues a famílias adoptivas, ou em estabelecimentos de assistência [inibindo-se o poder paternal ou tutelar, nestes dois últimos casos) ${ }^{24}$.

\subsubsection{Os menores desamparados}

Ao abrigo do Decreto de 1911, os menores desamparados eram aqueles que, isoladamente ou em grupo, viviam em habitual estado de: ociosidade, por viverem em casa dos pais ou tutores sem quererem estudar ou trabalhar, vagueando habitualmente pelas ruas; vadiagem, por terem fugido de casa, vagueando nas ruas e vivendo da mendicidade ou do furto; mendigagem, por habitualmente pedirem esmola para si ou para outrem; ou libertinagem, por viverem da prostituição de outrem, instigarem terceiros a praticarem actos obscenos, praticarem tais actos em casas destinadas à prostituição ou noutro local, ou se limitarem a viver ou a frequentar casas de passe, de jogo proibido

tutores por estes: não cumprirem os seus deveres de vigilância e de educação; terem mau comportamento notório; terem sido condenados a pena correccional por haverem cometido algum crime contra um ou mais filhos ou pupilos; serem conhecidos habitualmente por ociosos, men digos, vadios, alcoólicos, gatunos, rufiões, ou outros vícios imorais; exercerem sobre os seus fiIhos, de forma habitual ou excessiva, maus tratos físicos ou os privarem dos cuidados mínimos para a sua sobrevivência; os colocarem em profissões proibidas ou perigosas; ou os incitarem a praticar a mendicidade, gatunice ou prostituição [art. $26^{\circ}, n^{0} 4,5$ e 6 , ex vi $\operatorname{art} .41^{\circ}$ da L.P.I.]. 0 juiz presidente da tutoria, uma vez ouvidas as pessoas envolvidas, e após realizar um exame médico à criança ou jovem, podia determinar: a libertação dos pais ou tutor, entregando-lhes o menor; detê-los ou apresentá-los em tribunal criminal, inibindo-os de todo ou em parte do poder paternal ou tutelar [arts. $18^{\circ}$, § único, $19^{\circ}$ da L.P.I., $41^{\circ}, 42^{\circ}$ e $43^{\circ}$ da L.P...]. Neste último caso, 0 menor seria colocado "sob a guarda e defesa da República" (ou "sob a guarda da República" se a inibição fosse parcial) sendo entregue a um familiar que aceitasse cuidar dele ou, provisoriamente, internado no respectivo refúgio até o juiz determinar ou a sua entrega a uma instituição de assistência ou de federada até ser colocado em casa de famílias adoptivas ou "em estabele-

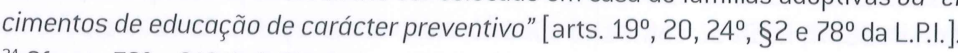

${ }^{24} \mathrm{Cf}$. arts $79^{\circ}$ a $81^{\circ}$ da L.P.I. 
ou de espectáculos pornográficos ${ }^{25}$.

Estas crianças e jovens continuaram, à luz da L.P.I., a ser equiparados, para efeitos de tramitação processual e medidas aplicadas, aos menores delinquentes. Não é despiciendo recordar que, em 1911, continuava em vigor o Código Penal de 1886 que ainda penalizava qualquer conduta de mendigagem ou vadiagem. Por outro lado, nos mesmos termos que fez para os menores delinquentes, alargou o âmbito de intervenção da L.P.I. aos menores com idade inferior a nove anos qualificados de desamparados: estas crianças e jovens tanto podiam ser entregues aos pais, se não estivessem "moralmente pervertidos", como internados numa instituição federada ou de assistência ou numa escola de preservação ou de reforma do Estado ${ }^{26}$.

\subsubsection{Os menores delinquentes}

Eram qualificados de menores delinquentes, os que, tendo idade compreendida entre os nove e os dezasseis anos, fossem condenados como auto res de uma contravenção, ou autores, encobridores ou cúmplices de um crime.

A Lei de 1911 fixou como limite etário de inimputabilidade os dezasseis anos, deixando de relevar o critério subjectivo e ambíguo que permitia a punição dos menores de catorze anos que tivessem agido com "discernimento". Quanto às crianças com idade inferior a nove anos, não podendo o juiz aplicar- Ihe nenhuma das medidas reeducativas indicadas na lei, aquelas deviam ser entregues aos pais ${ }^{27}$; no entanto, em termos semelhantes ao que ocorria para os menores desamparados, se houvesse indícios de que um desses menores se encontrava moralmente pervertido ou em perigo ${ }^{28}$, tinha ainda o juiz a faculdade de os internar numa instituição federada ou de assistência, ou numa escola de preservação ou de reforma do Estado, até atingirem a maioridade ${ }^{29}$.

0 legislador, absorvendo as novas correntes doutrinárias no âmbito do direito penal, compreendendo que os menores delinquentes, até atingirem determinado estado de maturidade física intelectual, não têm consciência "do carácter permitido e proibido dos seus actos, não os sabendo valorar do ponto de vista jurídico-moral”30 ${ }^{n}$, nem a liberdade necessária para se autodeterminar,

\section{${ }^{25} \mathrm{Cf}$ arts. $58^{\circ}$ a $61^{\circ}$ da L.P.}

${ }^{26}$ Cf. art. $76^{\circ}, \S 2$ da L.P.I

${ }^{27} \mathrm{Cf}$. art. $76^{\circ}$ da L.P.I.

${ }^{28} \mathrm{Cf}$. art. $76^{\circ}, \S 1$ da L.P.I.

${ }^{29} \mathrm{Cf}$. art. $81^{\circ}$ da L.P.I.

${ }^{30}$ Vide CARLOS ALBERTO ROSA DE CARVALHO JORDÃO, Menoridade e privação de liberdade no direito tutelar de menores, in "Scientia luridica", 14 (1965), pp. 302-303. procurou, neste novo enquadramento legal da L.P.I., sujeitá-los, não a medidas penais repressivas e intimidadoras, mas de correcção ${ }^{31}$, a cumprir em estabelecimentos específicos para menores ${ }^{32}$. 0 jovem deveria ser sujeito "a uma simples acção terapêutica, conforme a etiologia criminal revelada, pela reeducação moral, pela preparação profissional e até pelo tratamento das condicõos psico-patológicas, endógenas e exógenas, observadas no exame médico" ${ }^{33}$.

\subsubsection{Os menores indisciplinados}

Os jovens indisciplinados ${ }^{34}$, também designados de desobedientes e incorrigíveis, eram aqueles que, tendo idade inferior a vinte e um anos, os seus pais ou tutores ${ }^{35}$ haviam requerido o seu internamento (numa casa de correcção, num refúgio ou numa colónia correccional e pelo período máximo de seis

${ }^{31}$ Ao abrigo do Decreto de 1911, podiam ser aplicadas aos menores delinquentes, com idade superior a nove anos, nos termos do preceituado no seu art.63․ as seguintes medidas reeducativas, hierarquizadas em função do seu grau repressivo: "absolvição com repreensão, sendo o menor entregue aos pais; absolvição com repreensão, sendo os seus pais obrigados, durante um a dois anos, a garantirem o seu bom comportamento e a sua frequência regular numa escola); colocação em regime de liberdade vigiada com apresentação periódica perante o tribunal; aplicação de uma multa (paga pelos pais ou tutor); condenação no pagamento de uma indemnização, a ser paga pelos sues pais ou tutor à parte queixosa, ou nas custas do processo; colocação em liberdade vigiada; entrega a uma instituição federada ou de assistência, que o tenha aceite ou reclamado para ser colocado numa família adoptiva ou numa casa de simples educação, com suspensão do poder paternal; internamento até sessenta dias no refúgio da tutoria; internamento numa escola de reforma do Estado". No caso de se tratar de o menor com idade superior a treze anos, julgado pela prática de crime correspondente no código penal a uma pena maior, podia o juiz ainda aplicar uma medida de detenção numa casa de correcção, que podia ir de um a cinco anos, seguida ou não de internamento numa escol de reforma nos termos do art. $65^{\circ}$ da L.P.I. Com a entrada em vigor do decreto 10 76?, de 15 de Maio de 1925, as medidas supra enunciadas sofrem algumas mudanças de nomenclatura, tendo ainda sido introduzidas medidas complementares, designadamente: o semi-internato; liberdade condicional; alistamento no Exército ou na Armada.

${ }^{32}$ Neste sentido, e porque as tutorias comarcãs não tinham refúgios que os auxiliassem na detenção provisória de menores que fossem apanhados a praticar um crime muito grave (exigindo-se a sua imediata detenção), o legislador, no Decreto de 1925, veio determinar que aqueles podiam, excepcionalmente, ser recolhidos provisoriamente numa ala apropriada da cadeia civil exclusivamente destinada a menores. Cf. arts. $80^{\circ}$ e $81^{\circ}$ do Decreto no 10 ?67, de 15 de Maio de 1925.

${ }^{33}$ Cf. al. a) da Portaria $n^{0} 4882$, de 6 de Maio de 1927

${ }^{34} \mathrm{Cf}$. arts. $69^{\circ}$ a $72^{\circ}$ da L.P.I.

${ }^{35}$ Os tutores para requerem o internamento do menor indisciplinado, nos termos do art. 69 ${ }^{\circ}$, a] da L.P.I., precisavam de estar devidamente autorizados para o efeito pelo conselho de família, nos termos do art. $224^{\circ}, n^{0} 12$, do Código Civil de 1866 
meses] apresentando prova informatória da sua rebeldia e incorrigibilidade, designadamente de como eram adversos à ordem, à disciplina, aos estudos ou ao trabalho imposto na família e na escola, face aos mecanismos normais de correcção nesses meios [arts. $143^{\circ}$ e $224^{\circ}, n^{0} 12$ do Código de Seabra]

\subsubsection{Os menores anormais pathologicos}

Eram designados de menores anormais pathologicos os que sofriam de uma doença mental, fraqueza de espírito, epilepsia, histeria ou instabilidade mental, os quais passam a ter direito a um tratamento especializado em função da patologia diagnosticada ${ }^{36}$.

\subsubsection{Outras matérias}

Para além das questões referentes à infância e à juventude, as tutorias tinham competência para proceder ao julgamentos de adultos que incorressem na prática de um dos crimes expressamente tipificados no diploma legal contra menores $\left[\operatorname{art} .10^{\circ}, n^{0} 11 \text { da L.P.I. }\right]^{3 ?}$.

${ }^{36}$ Cf. arts. $73^{\circ}$ e $76^{\circ}, \S 3$, ambos da L.P.I.

${ }^{37} \mathrm{Cf}$. art. $10^{\circ}, n^{0} 11^{\circ}$ da L.P.I., que remete para os arts. $27^{\circ}$ e seu $\S$ único, $60^{\circ}$ e seu $\S$ único, $104^{\circ} \mathrm{e}$ seu §único, $103^{\circ}$ e seu §único e $107^{\circ}$, todos da L.P.I. Punia, assim, o legislador, os pais ou tutores que: maltratassem os seus filhos ou pupilos; os privassem dos cuidados mínimos indispensáveis à sua saúde; os empregassem em profissões proibidas ou perigosas [art. $\left.\left.26^{\circ}, n^{\circ} 5, a\right], b\right]$ e c] ex vi art.2 $7^{\circ}$ ambos da L.P.I]; os incitassem ou favorecessem o seu estado de desamparo ou delinquência [art. $26^{\circ}, n^{\circ} 5$, al. d], ex vi arts. $27^{\circ}$ e 10 ? todos da L.P.I]; os tentassem raptar, dar maus conselhos ou convidá-los à fuga da casa da família adoptiva ou de uma instituição onde estivessem internados [art. $104^{\circ}$ da L.P.I]; os abeirassem junto da escola, oficina, casa adoptiva ou de algum internato de educação com o fim de os raptarem, Ihes darem maus conselhos, os incitassem à fuga ou a maltratarem os seus protectores, tutores ou educadores (art $104^{\circ} \mathrm{da}$ L.P.I.); ou os que se recusassem a entregá-los às autoridades competentes (art. 104̊ $̧$ único da L.P.I.). Podia ainda ser condenada qualquer pessoa que concorresse para uma dessas situações (art.107 § único da L.PI]; explorasse, directa ou indirectamente, uma "casa de toleradas, ou de passe", casas de jogo proibido ou de espectáculos proibidos [art. $60^{\circ}$ da L.P.I.]; ou narrasse ou publicasse qualquer caso de vadiagem, mendicidade, libertinagem, contravenções ou crime

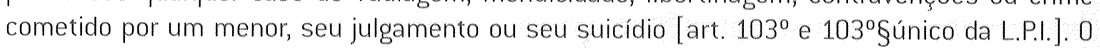
Dec.-Lei no 20 431, de 24 de Outubro de 1931, o Dec.-Lei no 35 955, de 19 de Novembro de 1946, o Dec.-Lei $n^{0} 2$ 053, de 22 de Março de 1952; e o Dec.-Lei $n^{0} 38$ 964, de 27 de Setembro de 1952, estenderam a competência das tutorias a outros tipos legais de crimes praticados por adultos contra crianças e jovens: com o Decreto n ${ }^{0} 20$ 431, de 24 de Outubro de 1931, punirse-á ainda: o não pagamento da prestação de alimentos; o incumprimento do poder paternal; a narração ou publicação de extractos dos julgamentos referentes a actos delituosos, de vadiagem, mendicidade ou libertinagem cometidos por menores; a sua frequência em lugares ou espectáculos imorais; o crime de lenocínio praticado sobre menores de vinte e um anos;
Em matéria cível, podiam ainda analisar questões relativas à inibição ou suspensão do poder paternal ou da tutela e ao pedido de alimentos ${ }^{38}$.

E, a partir de 1946, passam a ser responsáveis ainda por conceder autorização judicial a menores, entre os doze os dezasseis anos, para que pudessem proceder à venda ambulante de jornais ${ }^{39}$.

\subsection{APRECIAÇÃO CRÍTICA AO REGIME DA L.P.I.}

Não obstante o teor do novo texto legal denotar, o que alguns autores apelidaram de um certo romantismo político da época ${ }^{40}$, assente não no rigor técnico-jurídico, no conhecimento científico mas sobretudo empírico, na nova axiologia associada aos problemas da infância e da juventude, ele não deixou de significar uma viragem na forma de entender e enquadrar juridicamente tais questões.

Foi um instrumento de alcance inquestionável na forma como transpôs para o papel os princípios de uma nova corrente dogmática e jurisprudencial que apostava na intervenção preventiva e reeducadora face à delinquência e indisciplina juvenil, com recurso a uma "pedagogia correccional, ao trabalho profissional e uma terapêutica apropriada" ${ }^{41}$. Compreendeu-se que os jovens, para conseguirem alterar os seus comportamentos, contrários ao dever-ser jurídico-penal, para assimilarem os princípios e valores cívicos e morais, precisavam de ser motivados, orientados e valorados no seu esforço pessoal individual, no seu sentido de responsabilidade, de respeito, de disciplina, num

com o Decreto n ${ }^{0} 35$ 955, de 19 de Novembro de 1946: o emprego de menores de doze anos como vendedores ambulantes de jornais, e de menores com idade compreendida entre os doze e os dezasseis anos sem autorização do juiz; com o Decreto $n^{0} 2$ 053, de 22 de Março de 1952: o incumprimento da obrigação de alimentos fixada judicialmente e a falta de assistência económica ou moral dos pais, tutores, ou quem tivesse a guarda do menor; e, por fim, com - Decreto no 38 964, de 27 de Setembro de 1952, regulador da assistência de menores a espectáculos públicos (substituído pelo decreto n 41 051, de 1 de Abril de 1957): a permissão dos pais, tutores ou pessoas encarregues da educação ou simples vigilância dos menores no acesso destes a espectáculos que não fossem classificados para a sua idade e pudessem, por essa razão, "prejudicar a sua formação espiritual, o seu desenvolvimento moral e intelectual ou excitar perigosamente a sua sensibilidade e imaginação", despertando-thes "instintos doentios" ou corropendo-os; e a venda dos bilhetes ou a sua entrada nesses locais.

${ }^{38} \mathrm{Cf}$. arts. $171^{\circ}$ e ss. do Código de Seabra.

${ }^{39}$ Cf. art. 2 do Dec.-Lei ${ }^{0} 35$ 955, de 19 de Novembro de 1946

${ }^{40}$ Cf. EURICO SERRA, o.C., p. 18.

${ }^{41}$ Vide AUGUSTO D ' OLIVEIRA, in Protecção moral e jurídica à infância (Tipografia do Reformatório Central de Lisboa Padre António de Oliveira/ Lisboa, 1929), p. 24. 
ambiente o mais próximo possível ao partilhado no interior de uma família, sendo-Ihes ainda facultada instrução ou formação profissional como ferramentas essenciais para uma posterior integração na sociedade.

Consagrou, assim, a nova lei o primeiro regime jurídico penal e processual específico para os menores e os primeiros tribunais de competência especializada em matéria de infância e juventude, reorganizando as instituições tutelares de justiça, transpondo, assim, os referidos valores e princípios reeducativos. Nesse sentido, diminuiu-se o limite etário de imputabilidade para os dezasseis anos, independentemente de o menor ter agido ou não com "discernimento". 0 juiz presidente passa a decidir segundo o princípio da equidade e não da legalidade estrita, e numa perspectiva paternalista, como um bom pai de família. Não obstante o seu carácter proteccionista, consagrou "um modelo mais próximo do modelo híbrido que se viria a generalizar na Europa”, sem os "excessos que depois se censuraram aos sistemas welfare" ${ }^{42}$, sistema este que, em meados do século XX, vem a ser adoptado em Portugal.

No âmbito dos menores em perigo moral, o diploma estendeu o âmbito de protecção não só às crianças e jovens abandonados e órfãos como também àqueles sujeitos ao poder paternal e tutelar, se inseridos em quadros familiares de pobreza extrema ou de negligência e maus-tratos.

Não obstante o mérito reconhecido à L.P.I. nos referidos aspectos, são diversos os reparos que podem ser apontados ao seu regime legal.

Em primeiro lugar, em termos sistemáticos, o decreto apresenta deficiências de organização e de disposição, denotando falta de clareza e rigor técnico-científico, dificultando a sua leitura e compreensã $0^{43}$ (dificuldade essa ainda acrescida pelas inúmeras modificações a que foi sujeita ao longo dos anos].

Quanto ao seu regime substantivo, verificamos como o legislador subsumiu os menores por si tutelados a cinco categorias fundamentais: os menores em perigo moral, desamparados, delinquentes, indisciplinados e anormais patológicos.

Todavia, não obstante tenha previsto um conjunto de medidas distintas a aplicar a cada uma dessas categorias de menores, como bem alertava o Director-Geral dos Serviços Jurisdicionais de Menores, Eurico Serra, no Anteprojecto da reforma dos Serviços Jurisdicionais de Menores, em 1961, "a prática já de

${ }^{42}$ Cf. ANABELA MIRANDA RODRIGUES, A reforma do direito dos menores (o caso português), in "Anuário de Justiça de Menores" (Astigi/Sevilha, 2001), p. 31.

${ }^{43} \mathrm{~A}$ título de exemplo, entre as disposições legais sobre tramitação processual, entre a fase de inquérito e de julgamento, introduz disposições sobre a medida de liberdade vigiada, a obrigação de alimentos dos pais ou ascendentes e a possibilidade de um menor desamparado ou delinquente poder sair, definitiva ou sob liberdade condicional, de uma escola de reforma. há muito vinha fazendo letra morta destas classificações, não só aplicando a menores indisciplinados todas as medidas destinadas aos delinquentes, mas também socorrendo-se de artifícios processuais e de prova para classificar numa das restantes categorias os menores em perigo moral e consequentemente Ihes aplicar indistintamente umas e outras medidas" ${ }^{4}$. A distinção dos menores em função da sua situação factual e respectiva subsunção a uma determinada categoria revelava-se, assim, sobretudo formal e simbólica, não permitindo uma efectiva assistência e protecção às crianças e aos jovens em perigo na época, muitas vezes, sujeitos a medidas de reeducação.

Por outro lado, da análise do diploma resulta claro que a principal preocupação do legislador prendia-se com os menores delinquentes. A intervenção protectora junto das crianças e jovens em perigo era relevante na medida em que permitisse prevenir a delinquência juvenil ${ }^{45}$.

Refira-se ainda que o novo processo judicial especializado para área da infância e da juventude, embora conferisse maiores garantias processuais ao menor ( passa a ter direito a ser assistido por advogado, na fase de instrução, e, no julgamento, por um curador e um advogado, prevendo-se ainda a possibilidade de recurso dos despachos do juiz presidente e dos acórdãos definitivos ${ }^{46}$ ); visava não tanto conhecer a realidade dos factos mas sobretudo conhecer o menor, a sua situação pessoal e familiar, submetendo-o a exames médicos e pedagógicos. A medida aplicável aos jovens delinquentes ou paradelinquentes era aferida em função da sua personalidade e do grau do seu desvio comportamental e moldada com base na observação e análise subjectiva levada a cabo por médicos. Com efeito, adoptavam-se medidas terapêuticas flexíveis que pudessem ser adaptadas, prorrogadas ou alteradas em função do processo evolutivo do menor.

Acresce que, ao introduzir a categoria de menores indisciplinados, corolário do preceituado no Código Civil de Seabra, a lei de 1911 continua a reconhecer aos pais ou tutores um poder muito amplo sobre a vida dos menores a seu cargo, permitindo-Ihes requerer ao tribunal o seu internamento, em escolas de reforma, sempre que aqueles não obedecessem às suas ordens e orientações. A indisciplina traduzia-se num conceito muito vasto e elástico, que permitia incluir situações de mera irreverência ou de actuação de acordo com os seus

${ }^{44}$ Vide EURICO SERRA, ibidem, p. 76.

${ }^{45}$ Também neste sentido, vide PEDRO AUGUSTO LISBOA DE LIMA CLUNY, O direito tutelar de menores e o problema da sua autonomia, in "Scientia luridica", 10 [1961], p. 15?.

${ }^{46}$ Cf. arts. $96^{\circ}, 97^{\circ}$ e $98^{\circ}$ da L.P.I. 
valores, se distintos dos do detentor da sua guarda, uma vez que ao menor não se the reconhecia autonomia, nem liberdade de expressão.

Quanto aos menores em perigo moral, ressalta o facto de o legislador ter fixado de forma taxativa, e não a título meramente exemplificativo, as situações que poderiam recair nessa categoria legal, limitando, desse modo, a acção das tutorias, designadamente quando estivessem em causa situações de abuso ou de maus-tratos de índole psicológica.

Incluiu ainda na referida categoria os menores pobres, porém a possibilidade de assistência a essas crianças encontrava-se restrita às que ainda não tivessem completado os doze anos e cujos pais ou tutor aceitasse declarar não se opor a tal intervenção e o juiz entendesse necessária a sua saída de casa.

Não se intervinha preventivamente junto das famílias, nem se lhe presta va qualquer apoio no sentido da sua regeneração.

Urgia ainda proceder a uma adequada reestruturação dos serviços jurisdicionais de menores, que melhor respondesse ao novo modelo proteccionista, e reestruturar os estabelecimentos de internamento dos menores delinquentes ${ }^{4 ?}$.

\footnotetext{
47 Sendo a medida de internamento a mais aplicada pelas tutorias, e sendo esta a mais estigmatizante para o menor, havia que procurar medidas alternativas que, sendo exequíveis, simultaneamente espelhassem a sua intencionalidade reeducativa e a rápida e reintegração daquele na sociedade. Repudia-se, assim, a concepção tradicional de que a reeducação de um jovem inadaptado exige o seu afastamento do seu contexto sócio-familiar, das pessoas e dos locais que o desviaram do caminho do bem, e a sua colocação em instituições fechadas para que, através de uma rígida disciplina, alcance a sua regeneração moral. Novos estudos médicos e psiquiátricos alertavam para a ocorrência de um verdadeiro traumatismo psíquico e afectivo em todas as situações em que um menor é afastado da sua família e do seu meio natural de vida. Por outro lado, quanto aos estabelecimentos de internamento, mostrava-se ainda necessário pôr fim à divisão neles operada pelo Decreto de 1925, que distinguira os Reformatórios, locais de internamento dos "menores delinquentes ainda não gravemente pervertidos", das Colónias Correccionais, direccionadas especialmente para acolher "os menores em mais adiantado estado de perversão", onde a disciplina era mais rígida e inflexível, próxima à vivida no interio das prisões. Havia que obliterar de vez, no novo sistema tutelar, todo e qualquer resquício do velho espírito repressivo e intimidativo face à delinquência juvenil, que o regime legal imposto pelo decreto de 1911 não conseguira afastar na globalidade. Aos olhos da sociedade e do próprio menor delinquente, quando este era colocado por decisão da tutoria numa Colónia Correccional, era como se tivesse sido condenado a uma verdadeira pena. Havia que começar a criar estabelecimentos de internamento de carácter reeducativo, sobretudo ao nível do semiinternato, com pequenas dimensões, onde fosse possivel criar um ambiente acolhedor, familiar onde o menor pudesse ter um tratamento individualizado e sentisse as suas opiniões e as suas necessidades afectivas, psicológicas e físicas satisfeitas, um local onde a disciplina fosse menos autoritária e mais pautada pela compreensão, e o menor preparado, através do ensino profissional e técnico, para o seu retorno activo à sociedade.
}

Em suma, podemos concluir que a criança, ao abrigo da L.P.I, continua sem ser compreendida como um sujeito titular de direitos fundamentais, mas sim um ser que, devido à sua vulnerabilidade e à sua dependência, precisa de ser apenas protegido ou reeducado, consoante as circunstâncias de cada caso, com vista a garantir a sua sobrevivência, "educação e purificação"48.

A L.P.I. manteve-se em vigor até à década de sessenta, altura em que se procede à grande reforma do sistema tutelar de menores, com a promulgação da Organização Tutelar de Menores, aprovada pelo Dec.-Lei nº 44 288, de 20 de Abril de 1962, a qual procurou embutir uma nova visão e novos princípios fundamentais neste sector especializado do direito.

\section{A ORGANIZAÇÃO TUTELAR DE MENORES}

\subsection{FINALIDADE E ÂMBITO DE APLICAÇÃO}

A pedra de toque do novo sistema tutelar residiu no seu cariz acentuadamente proteccionista, no qual sai reforçado o papel do Estado na tríplice função de "proteger, assistir e educar" qualquer "menor-problema". Uma figura paternal que substitui os pais e os educadores na prossecução do que entende ser o melhor interesse para cada criança ou jovem, com amplos poderes de intervenção, através dos respectivos órgãos judiciais.

Institui-se, assim, um tipo de processo judicial informal no qual o juiz detém em exclusivo o poder decisório, considerando-se despicienda a consagração de quaisquer garantias de defesa individuais ao menor e ao seu representante legal ( tais como o contraditório, o direito a apresentar requerimentos de prova ou a ser assistido por um advogado].

Os tribunais tutelares passam a ser formados por um único juiz de direito, um curador de menores ${ }^{49}$ (responsável por velar pelos direitos de cada criança ou jovem, por os representar em juízo e interpor as devidas acções em defesa dos seus interesses], e uma secretaria.

Por seu turno, extinguem-se as categorias que o Decreto de 1911 introduzira entre menores delinquentes, em perigo moral, desamparados ou incorrigíveis, aplicando-se-Ihes as mesmas medidas de protecção, assistência e educação ${ }^{50}$.

\section{${ }^{48}$ Cf. Preâmbulo da L.PI.}

${ }^{49}$ A função de curador seria desempenhada por um delegado ou subdelegado do Procurador da República ou por quem legalmente o substituísse. Cf. arts. $3^{\circ}, n^{0} 1,8^{\circ}$ e 12 da 0.T.M.

${ }^{50}$ Medidas essas taxativamente enunciadas, no art. $21^{\circ}$ da 0.T.M., que podiam ir desde uma mera admoestação, à colocação do menor em regime de aprendizagem ou de trabalho em empresa por entidade particular ou em instituição oficial ou privada, ou o seu internamento 
Acentua-se no espírito da lei a percepção das crianças e jovens, agentes de ilícitos criminais ou de condutas para-delinquentes, como meras vítimas da sociedade, os quais devem ser protegidas do seu meio ambiente familiar e social e das suas más tendências e reeducados como qualquer criança em perigo moral. Mais importante que reprimir ou punir a sua conduta, passa a ser "combater neles ou no ambiente que os rodeia as causas que os arrastaram ao foro tutelar", resultante "de causas complexas de ordem psíquica, familiar e social" ${ }^{51}$. Assim, no momento da selecção da medida a aplicar o juiz devia considerar designadamente as particulares circunstâncias psicológicas, familiares e sociais do jovem e não a prova dos factos indiciados ${ }^{52}$. As medidas mantêm uma estrutura maleável de modo a permitir que o julgador possa aplicá-las em função das específicas necessidades educativas de cada menor (reveladas pela sua personalidade, contexto sócio-familiar e resultado da terapêutica administrada através da observação científica].

\subsection{A PRIMEIRA ALTERAÇ̃̃O À O.T.M.}

0 regime legal vertido na 0.T.M. foi objecto de reforma, em 1967, com a publicação do Dec-Lei n ${ }^{0} 47$ 727, de 23 de Maio, em consequência da publicação do novo Código Civil de $1966^{53}$, que reformulou, designadamente, alguns dos seus preceitos em matéria de providências cíveis.

Na nova versão do diploma, os menores em situação de perigo deixam de

em estabelecimentos oficiais ou particulares de educação ou em institutos de reeducação Previa, ainda, para os jovens com mais de dezoito anos, inadaptados ao regime dos institutos de reeducação e com adiantado estado de rebeldia, a medida de internamento em prisão - escola ou estabelecimento equivalente [art. $22^{\circ}$ da 0.T.M.].

${ }^{51}$ Cf. §̧2 do ponto 18 e §̧2 do ponto 26 do Dec.-Lei n 44 287, de 20 de Abril de 1962.

${ }^{52}$ Cf. §̧2, ponto 26 do Dec.-Lei n ${ }^{0} 44$ 287, de 20 de Abril de 1962

${ }^{53} 0$ C.C., na versão de 1966, entrou em vigor a 1 de Junho de 1967. Neste novo regime jurídico civil, mantém-se a visão das crianças e os jovens como sujeitos-objecto do poder paternal dos seus pais, a quem devem honrar e respeitar de forma absoluta [art. $1867^{\circ} \mathrm{do} \mathrm{C.C.],} \mathrm{permanecendo}$ diferenciados na lei em função do seu estatuto legal de legítimos ou ilegítimos. Em matéria de exercício das responsabilidades parentais relativamente a filhos legítimos, destaque-se de positivo na versão do C.C. de 1966, por um lado, o facto de atribuir a ambos os progenitores a guarda e a regência dos filhos menores não emancipados, competindo-lhes "defender, educar, alimentar, representar e administrar os bens daqueles" [art. $1879^{\circ}$ do C.C.]; ter determinado a irrenunciabilidade do poder paternal; sujeitado a autorização judicial certos actos de administração de bens dos filhos [arts. $1880^{\circ}$ e $1887^{\circ}$ do C.C .]; e reconhecido à progenitora, para além do direito a ser ouvida em tudo o que dissesse respeito aos interesses do seu filho, o poder de autorizá-la a praticar certos actos previstos na lei e de poder substituir o marido, quando este se encontrasse em local remoto, desconhecido ou se encontrasse impossibilitado [art. $1882^{\circ}$ do C.C.] ter previsão legal, podendo apenas o julgador, até 1978, aplicar-Ihes a medida de regime de assistência ${ }^{54}$, prevista no art. $21^{\circ}, \mathrm{h}$ ), a qual consistia em sujeitar os pais, tutores ou quem tivesse a sua confiança ou guarda do menor, a um conjunto de orientações ou a fiscalização relativamente à forma de exercício do poder paternal.

\subsection{A SEGUNDA ALTERAÇ̃̃̃ À O.T.M}

Em 1978, é aprovado o Dec-Lei 314/78, de 27 de Outubro ${ }^{55}$, o qual, sem afectar a estrutura sistemática da O.T.M, nem reformular os seus princípios nucleares, introduz importantes modificações ao seu regime ao incorporar novas formas de participação da comunidade na administração da justiça, no seguimento dos novos valores constitucionais proclamados na C.R.P. de $1976^{56}$ e na reforma da organização dos tribunais judiciais ${ }^{5}$.

Por um lado, é criada a figura dos juízes sociais ${ }^{58}$, cidadãos activos da

${ }^{54}$ Vide ELIANA GERSÃO, Comissões de protecção de menores: uma proposta esquecida? in "Revista Infância e Juventude", 4 [1977), pp. 8-12.

${ }^{55}$ Entrou em vigor no ordenamento jurídico interno a 31 de Julho de 1978.

${ }^{56}$ A C.R.P. de 1976 concedeu especial protecção à infância e à juventude, tendo enunciado novos princípios em matéria de família e infância e juventude. Consagrou, assim, a todas as crianças o "direito à sua protecção pela sociedade e pelo Estado com vista ao seu dim, a todas as crianças o especialmente contra todas as formas de abandono, de discriminação e de opressão e contra o exercício abusivo da autoridade na família e nas demais instituições" [art. $69^{\circ}$ da C.R.P.]; reconheceu especial protecção às crianças órfãs, abandonadas ou por qualquer forma privadas de um ambiente familiar normal [art. $69^{\circ}, n^{0}$ 2, da C.R.P.] e aos jovens " para fectivaçõo privadas de um económicos, sociais, culturais, nomeadamente no ensino, na formação profissional e na cultura, no acesso ao primeiro emprego, no trabalho e na segurança social, no acesso à habitação, na educação física e no desporto, no aproveitamento dos tempos livres [art. $70^{\circ}$ da C.R.P.]; proibindo expressamente qualquer forma de discriminação dos filhos nascidos fora do casamento [art. $36^{\circ}$ $n^{0} 4$, da C.R.P.]. Enuncia a instituição família ça $n^{0} 1$, da C.R.P.], a qual tem direito "a ser protegida pela sociedade e pelo Estado" [art. $67^{\circ}, n^{0} 1$, da C.R.P.], baseada na "igualdade de direitos e deveres entre os cônjuges, nomeadamente no que toca à manutenção e educação dos filhos", e na "proibição da discriminação dos filhos nascidos fora do casamento". Nessa medida, estabelece limites de ingerência familiar, só permitindo a separação dos filhos dos seus pais em casos pontuais em que o interesse superior do menor o justifique [art. $36^{\circ}, n^{\circ} 6$ da C.R.P. ]

57 Reforma essa levada a cabo pela Lei $n^{\circ} 82 / 7 ?$, de 6 de Dezembro, que repartiu entre os tribunais de menores e os tribunais de família as matérias que até então repartiu entre os competência dos primeiros.

${ }^{58}$ Coube ao Dec.- Lei no 156/78, de 30 de Junho, regulamentar o regime de recrutamento e funções dos juízes socais, o qual permanece ainda hoje em vigor. Os candidatos são seleccionados de entre os cidadão residentes na área do município do tribunal de família e de menores ou do tribunal de 
comunidade e sem especiais conhecimentos na área do direito, que são chamados a auxiliar o juiz de menores no julgamento e na tomada de decisão de determinados casos indicados na lei ${ }^{59}$.

Referia, nesse sentido, o legislador que o exercício da função de juiz social constituía um "serviço (público) obrigatório para os cidadãos nomeados" do qual apenas se podiam eximir em casos muito específicos, taxativamente enunciados na lei ${ }^{61}$. Visou-se, desse modo, aproximar a opinião pública dos tri bunais e o juiz da comunidade: por um lado, sensibilizar os juízes relativamente aos "valores sociais dominantes e suas prioridades"; e, por outro, esclarecer a comunidade dos trâmites legais e da relevância da digna função da adminis-

comarca, cabendo à respectiva câmara municipal elaborar a respectiva lista de candidatos, a qua é posteriormente votada na Assembleia Geral do Município da sede do respectivo tribunal e enviada, em Junho, ao Conselho Superior de Magistratura e ao Ministério da Justiça. Os candidatos, para além de terem se ser conhecidos como pessoas idóneas, têm de ser cidadãos portugueses, com idade compreendida entre os vinte e cinco e os sessenta e cinco anos, que saibam ler e escrever português, e se encontrem no pleno gozo dos direitos civis e políticos, sem estarem pronunciados, nem terem sofrido qualquer condenação por crime doloso. Após aprovação da lista de candidatos pelo Ministro da Justiça, e decorrido o prazo de dez dias de reclamação, aquela deverá ser afixação no respectivo tribunal, sendo os juízes sociais nomeados por despacho do Ministro da Justiça arts. $6^{0} ; 20^{\circ}, n^{0} 2 ; 23^{\circ} ; 37^{\circ}$; e $38^{\circ}$ do Dec.-Lei $n^{0} 156 / 78$, de 30 de Junho]

${ }^{59}$ Ao contrário do que vigorava na versão original da 0.T.M., que optara pela manutenção de um único juiz no julgamento das causas da competência dos tribunais tutelares, adopta-se agora um regime mitigado que fixa como regra a singularidade mas impõe a constituição de um tribunal colectivo, formado por juiz de direito e dois juízes sociais, em duas situações particulares: a) quando a entidade judicial presuma que na situação em análise se aplicará uma medida de colocação em lar de semi-internato, colocação em instituto médico-psicológico ou em estabelecimento de reeducação; b] ou quando esteja em causa um jovem, com idade superior a dezasseis anos, que, durante o cumprimento de uma medida, cometa uma infracção criminal, se a sua personalidade e as circunstâncias pouco graves do facto assim 0 aconselharem [arts. $5^{\circ}$, $\mathrm{n}^{0} 1$ e 2; e $61^{\circ}$ da 0.T.M.].

${ }^{6}$ Cf. art. $4^{\circ}$ do Dec.-Lei ${ }^{0} 156 / 78$, de 30 de Junho.

${ }^{11}$ Nos termos do art. $3^{\circ}$ do Dec.-Lei no 156/78, de 30 de Junho, podem requerer escusa do cargo de juiz social: os militares no activo; quem padeça de doença ou anomalia que dificulte o exercício do cargo; e quem apresente razão considerada justificativa, desde que não susceptível de compensação pecuniária. Consideram-se ainda dispensados do cargo: o Presidente da República; os membros do Conselho da Revolução (esta alínea não foi revogada, não obstante te deixado de ter eficácia); os membros da Assembleia da República e das Assembleias Regionais; os membros do Governo Central e dos Governos Regionais; os magistrados judiciais e do M.P. os ministros de qualquer religião; os que padeçam de doença ou anomalia que impossibilite 0 exercício do cargo; e as pessoas em relação às quais se verifiquem as causas de impedimento ou os motivos de suspeição a que estão sujeitos os juízes de direito, nos termos dos arts. $2^{\circ} \mathrm{e}$ $8^{\circ}$ do citado diploma. tração da justiça ${ }^{62}$.

A segunda importante alteração introduzida ao regime da O.T.M., traduziu-se na criação de comissões de protecção, uma forma de intervenção administrativa, em alternativa à judicial, na tarefa precípua de protecção de crianças e jovens carentes de protecção, assistência ou educação.

A favor de um tipo de sistema social de protecção de menores apontava-se o facto de esta poder facilitar a "cooperação da família ou do representante legal" da criança ou jovem, por a sua intervenção não revelar carácter reprovador ou intimidante; evitaria ainda o estigma da criança ou do jovem de ter de se apresentar em tribunal; e permitiria que uma autoridade administrativa, formada por técnicos dos diversos ramos sociais do saber, pudesse recorrer a uma panóplia de medidas, e num ambiente informal, para melhor responder à problemática de cada criança ou jovem ${ }^{63}$.

Nesta sua primeira versão, as comissões de protecção surgem como meros órgãos de gestão dos centros de observação e acção social, instituições "oficiais não judiciárias de protecção de menores", ligadas apenas aos tribunais de menores de Lisboa, Coimbra e Porto, e constituídas apenas por elementos dos serviços públicos ${ }^{64}$.

${ }^{62}$ Estes objectivos encontram-se enunciados no preâmbulo do Dec.- Lei n⿳0 156/78, de 30 de Junho. ${ }^{63} \mathrm{Em}$ sentido contrário, advogava-se que este tipo de protecção social prejudicava os direitos e liberdades individuais do menor e do titular do exercício do poder paternal ou tutelar e que, ao desvalorizar os factos praticados pelo menor, se orientava "pela sua própria concepção de adaptação social e de interesses do menor". Cf. ELIANA GERSÃO, Comissões de proteç̃̃̃o: uma proposta esquecida?, in "Revista Infância e Juventude", 4 [ 1977), pp. 7-8.

${ }^{64}$ Como salientava ROSA CLEMENTE, in Inovação e Modernidade no Direito de Menores, A Perspectiva da lei de protecção de crianças e jovens em perigo, 16, Faculdade de Direito da Universidade de Coimbra, Centro de Direito da Família (Como, 16, Faculdade de Direito da 135-136: "os primeiros exemplos deste movimento forma e Comunitárias, criadas na Suécia pela Lei de Protecção à Infância, de 1961, e o modelo belga consagrado na Lei de Proteç̧ão da Juventude, de 1965, que adaptou as Comissões de Protecção de Menores a nível mundial a expressão mais significativa desta tendência no direito de menores é, à época, representada no modelo que serviu Protecção canadianos, criados pela Lei de Protecção à infância acrescentava ainda ELIANA GERS ̃̃O, Comissões de proteço: uma proposa cit., pp. 7-8, como a comisceç̃ão: uma proposta esquecida?..., cit., pp. 7-8, como as comissões de protecção foram introduzidas em vários países da Europa assumindo distintas posições face à actuação dos tribunais: nuns países, como na Suécia substituíram na totalidade a intervenção dos tribunais de mes. nuns paises, como na Suécia Federal, assumiram funções complementares ao poder judicial, substituindo-o apenas em relação a certos grupos de crianças que, pela sua idade, ou por se encontrarem em perigo, não recaíam sob a sua esfera de acção; e ainda, em países como a Bélgica, actuaram conjuntamente com o poder judicial, relativamente a menores em perigo, tendo como pressuposto de 
Para além de coadjuvarem os tribunais e os estabelecimentos tutelares, procedendo à observação do menor e à execução de medidas decretadas pelo juiz, passam também a poder, em determinados casos específicos, aplicar medidas de protecção, designadamente: a) a menores com idade inferior a doze anos, b] considerados delinquentes, desamparados ou inadaptados à vida social; c] quando os pais ou representante legal consentissem expressamente na intervenção ${ }^{65}$.

As comissões foram objecto, em 1991, de uma profunda reforma, com o Dec.-Lei $n^{0} 189$, de 17 de Maio $^{66}$, diploma este que veio a ser revogado com a

intervenção o acordo das pessoas por ele responsáveis

${ }^{65}$ Ou em alternativa, se não tivesse sido possível a notificação dos pais (ou representante legal do menor] para que estes pudessem prestar o seu consentimento expresso em relação à intervenção, este fosse suprido pelo representante do Ministério Público [art. $76^{\circ}$ da 0.T.M.]. ${ }^{66} 0$ Dec.-Lei no 189, de 17 de Maio de 1991 procedeu a uma importante reestruturação das comissões de protecção: exigia-se que estas fossem formadas não só por técnicos qualificados, mas também por cidadãos da comunidade, sem especiais habilitações, que revelassem especia interesse e capacidade de intervenção nesta área do direito; que revelassem qualidades que as permitissem distinguir dos tribunais pelo público em geral; que não constituíssem entidades subalternizadas, meros órgãos de gestão dos C.O.A.S.; que a sua intervenção não se restringisse às áreas correspondentes às sedes dos tribunais de menores mas a todas as comarcas; que pudessem intervir em todas as situações de menores em perigo, independentemente da sua idade; e que se responsabilizasse a "comunidade local pelas suas crianças e jovens, em total respeito e cola boração com a família". As comissões de protecção, ao abrigo do novo diploma legal, mantêm-se como instituiç̃oes oficiais não judiciais, integradas no Ministério da Justiça através do organismo que detivesse a competência sobre os Serviços Tutelares de Menores, com autonomia funcional. Passam a exercer a sua actividade a nível local, prevendo-se a sua criação em todas as comarcas do país [art. $2^{0}, n^{0} 1$ ], atribuindo-se ao município a responsabilidade de Ihes facultar apoio logístico e o que demais se revelasse necessário. Deveriam ser compostas por representantes de organismos e sectores muito diversificados: um agente do Ministério Público, em serviço na comarca; um representante do município a indicar pela Câmara; do centro regional de segurança social; dos serviços locais do Ministério da Educação; do Instituto da Juventude; das instituições privadas locais de solidariedade social; um psicólogo; um médico, em representação dos centros de saúde; das forças de segurança; e da associação de pais [art. $13^{\circ}$. Alargou-se ainda a sua esfera de acção, permitindo que pudessem intervir junto de qualquer: a] as criança ou jovem que se encontrasse numa situação de perigo com idade até aos dezoito anos [arts. $3^{\circ}, \mathrm{n}^{0} 2 ; 4^{\circ}, \mathrm{n}^{0} 1 ; 5^{\circ}$ ], b] visando "prevenir ou pôr termo a situações susceptíveis de afectar a (a sua) integridade física ou moral ou de pôr em risco a sua inserção na família e na comunidade" [art. $3^{\circ}, n^{0} 1$ ]. A legitimidade da sua intervenção fica, todavia, condicionada à verificação de três requisitos: ter competência territorial (aferida no momento da sinalização da situação e era fixada em função do local de residência do menor, ou, se esta não fosse conhecida, do local onde fosse encontrada); ter competência materia (podem intervir e aplicar medidas de proteç̧ão, com exclusão da de internamento a crianças e jovens com idade inferior a doze anos que mostrassem "dificuldade séria de adaptação a um vida social normal, pela sua situação, pelo seu comportamento ou pelas tendências que houves- entrada em vigor da actual L.P.C.J.P., a qual procurou suplantar algumas das falhas que foram sendo apontadas ao seu trabalho, ao nível da sua operacionalidade e eficácia, designadamente: a falta de princípios e directrizes comuns na criação local e espontânea das comissões de protecção; a inexistência de coordenação a nível nacional de todas as comissões e "de articulação no terreno" com "os serviços ou instituições intervenientes em matéria de família e infância"6?; $a$ insuficiência de estabelecimentos de acolhimento para dar resposta a todas as necessidades, de material de trabalho, de adequadas condições logísticas e de pessoal técnico, designadamente da área da psicologia, a tempo inteiro; e o desrespeito pelo direito da criança e da sua família à sua privacidade, com a intervenção de uma comissão demasiado alargada e com excessivas intervenções ${ }^{68}$

Por último, cumpre assinalar que a nova versão da 0.T.M. reintroduz a categoria de menores em perigo moral, que o Dec.-Lei $n^{0} 47727$ extinguira, em $1967^{69}$.

sem revelado"; se entregassem "à mendicidade, vadiagem, prostituição, libertinagem, abuso de bebidas alcoólicas ou uso ilícito de estupefacientes"; ou fossem "agentes de algum facto qualificado pela lei penal como crime ou contravenção" [art. 18º]. Tinham ainda competência para aplicar medidas a menores de dezoito anos "vitimas de maus tratos, de abandono ou de desamparo ou se encontrem em situações susceptíveis de porem em perigo a sua saúde, segurança, educação ou moralidade

${ }^{67}$ Cf. GRAÇA FONSECA e JOÃO PEDROSO, As comissões de proteç̧ão: caminhos a percorrer na promoção da cidadania das crianças e jovens, in "Intervenção Social", $17 / 18$ (1998), pp. 45-46. ${ }^{68}$ Com o intuito de solucionar algumas dessas problemáticas enunciadas, já havia sido criada em 1998, a Comissão Nacional de Protecção das Crianças e Jovens em Perigo, pela Lei nº 98/98, de 18 de Abril, dependente do Ministro da Justiça e do Trabalho e Solidariedade Social, a quem fora atribuída a função primordial de "acompanhar e apoiar as comissões de protecção, permitindo-Ihes melhorar a qualidade do seu desempenho" [art.1 ${ }^{\circ}, n^{\circ} 2$, i] ] e avaliá-las [art. $33^{\circ} \mathrm{da}$ L.P.C.J.P.]. Como frisava GUILHERMINA MARREIROS, As Comissões de Proteç̧ão de Crianças e Jovens. 0 papel das Comissões na Promoção dos Direitos e na Protecção das Crianças e Jovens, in "Revista Infância e Juventude", 2 (2004), pp. 29-30, a sua acção torna-se fundamental na atribuição de competências aos técnicos que lidam diariamente com as situações de crianças e jovens em perigo, proporcionando-Ihes formação e informação adequadas, dirigindo-Ihes directivas genéricas relativamente às metodologias mais eficazes a adoptar de forma concertada por todas as comissões e auxiliando-as na resposta a problemas equacionados ao nível local sobre questões sobre o seu desempenho, recursos e equipamentos disponíveis.

${ }^{69}$ A citada Lei n ${ }^{0} 82 / 77$, de 6 de Dezembro reformulou ainda algumas das disposições da 0.T.M. em matéria de estabelecimentos tutelares (redefinindo os seus fins e conferindo maior importância aos lares de semi-internato], suprimiu algumas medidas tutelares, reintroduz a medida "de imposição de determinadas condutas ou deveres", na al. c) do art. $18^{\circ}$ do citado diploma, e reformulou alguns artigos em matéria providências cíveis, designadamente, no âmbito do pro- 


\subsection{APRECIAÇÃO CRÍTICA AO REGIME DA O.T.M.}

0 modelo de intervenção enunciado na O.T.M., em matéria de infância e juventude, começou a ser questionado não apenas com a crise dos Estados-Providência defendendo-se formas alternativas, não judiciais, de assistência à infância), mas sobretudo com o brotar dos sistemas de justiça, que questionavam a óptica estritamente proteccionista dirigida aos jovens agentes de ilícitos criminais, e com a proclamação dos novos princípios fundamentais que deveriam nortear esta área do direito, vertidos na C.R.P. de 1976 e na Convenção dos Direitos da Criança de 1989.

No regime proteccionista da O.T.M., o Estado irrompia como uma figura paternal, o bom tutor que zelava por todas as crianças e jovens carentes de assistência e protecção, quer por assumirem comportamentos desviantes em relação ao padrão normal de conduta social, quer por se encontrarem em situação de perigo. Actuando, através dos seus órgãos judiciais, "para o bem e no interesse do menor", eram-Ihe reconhecidos poderes ilimitados de acção que, em muitas situações, se traduziam numa ingerência abusiva na vida do menor e da sua família, com claras restrições, inconstitucionais, dos seus direitos fundamentais (do direito à liberdade e à auto-determinação pessoal do menor e do direito à educação e manutenção dos filhos dos seus progenitores].

Ora, a consagração de um Estado de direito material, democrático, com o consequente reconhecimento de direitos e garantias fundamentais a todos os seus cidadãos, impunha a rejeição e obliteração dessa figura paternal, assim como qualquer forma de restrição a esses direitos, que não a título excepcional e em nome de outros direitos ou interesses constitucionalmente protegidos ${ }^{70}$.

Nessa medida, reconhecendo-se o direito de todas crianças e jovens a crescerem no seio da sua família e a não serem apartadas dos seus pais, salvo se tal correspondesse ao seu melhor interesse ${ }^{71}$, a intervenção estadual apenas deveria ter lugar na estrita medida em que os detentores das responsabilidades parentais não se revelassem capazes de o fazer ou fossem os causadores da situação de perigo [ao abrigo do art. $69^{\circ}$ da C.R.P.], sendo norteada pelo seu superior interesse. Princípio esse sustentado não em concepções subjec-

cesso de adopção, de regulamentação do poder paternal, na acção de alimentos, de entrega judicial de menores e de averiguação oficiosa da maternidade e da paternidade. Vide EPIFÂNIO, Rui e FARINHA, António, in Organização Tutelar de Menores. Contributo para uma visão interdis ciplinar do direito de menores e de família, (Livraria Almedina/Coimbra, 1992), pp. 7-10.

${ }^{20} \mathrm{Cf}$. art. $18^{\circ}$ da C.R.P. Vide ainda ANABELA MIRANDA RODRIGUES, o.c., pp. 358-359.

${ }^{71}$ Cf. art. art. $36^{\circ}, n^{0} 5$ e 6 da C.R.P. tivas e discricionárias do julgador?2, mas tendo presente o quadro mínimo de direitos sociais, políticos e cívicos reconhecido a todas as crianças e jovens.

Questionava-se, assim, não apenas a sua falta de "legitimação" de intervenção, mas a sua própria "eficácia"’3, na medida em que não conseguia responder de modo satisfatório nem às situações de menores em situação de perigo, nem aos casos mais graves dos menores que cometiam práticas delinquentes.

Por um lado, não se podia continuar a fundir no mesmo quadro de intervenção os menores em perigo e os delinquentes, sujeitando-os ao mesmo tipo de processo e a medidas semelhantes.

Permitindo que a escolha da medida fosse em função da sua possível exequibilidade, face às possibilidades reais dos serviços e instituições de acolhimento $^{74}$, na falta destas instituições de assistência adequadas, muitos menores em perigo ou com "forte propensão para a mendicidade, vadiagem, prostituição, libertinagem ou indisciplina" ${ }^{n 5}$, eram colocados a partilhar as mesmas instituições com jovens com mau passado de delinquência.

A acção dirigida aos menores delinquentes não podia permanecer numa óptica estritamente proteccionista, que os percepcionava como mera vítimas da sociedade, relegando-se para segundo plano a análise e prova dos factos indiciados na participação. Havia que responsabilizar os menores agentes de infracções criminais pelos actos por si praticados, sujeitando-os a medidas tutelares na medida em que necessitassem de serem educados para o direito?6

Sendo as medidas aplicadas em função das necessidades de protecção e educação do menor, e estas aferidas em atenção ao seu circunstancialismo familiar e social, na grande maioria dos casos, eram apenas as crianças provenientes de meios sociais mais pobres que eram sujeitas a medidas de internamento (quando na verdade deveriam ser assistidas através de mecanismos da assistência social), ficando impunes os jovens delinquentes pertencentes às

72 Cf. ANABELA MIRANDA RODRIGUES, o.c., p. 358.

${ }^{73}$ Cf. RUI ASSIZ, o.C., p. 158.

${ }^{74} \mathrm{Cf}$ art. arts. $18^{\circ}, 25^{\circ}$ e $52^{\circ}$ da 0.T.M.

${ }^{25} \mathrm{Cf}$. art. $24^{\circ}, \mathrm{n}^{\circ} 1$ da 0.T.M.

${ }^{76}$ Cf. ELIANA GERSÃO, Portugal entre as Armadilhas da "Protecção"e da "Justiça" de Menores, in "Tribuna de Justiça”, 4-5 (1990), pp. 100-101; e ANABELA MIRANDA RODRIGUES, o.c., pp. 374-386, sublinhando esta última autora como os menores com idade inferior a doze anos, que incorressem na prática de factos qualificados como crimes pela lei penal, não deveriam ser sujeitos ao mesmo regime legal dos menores delinquentes, devendo adoptar-se "a tendência generalizada na Europa para a descriminalização absoluta dos (seus) comportamentos". 
classes média e alta da sociedade??

Por outro lado, o regime em vigor admitia um tipo de processo tutelar informal, no qual todos os poderes se encontravam concentrados nas mãos do juiz de menores, a quem eram conferidos poderes discricionários no momento da selecção, modificação e fixação da duração das medidas tutelares, as quais, em muitos casos, só se extinguiam quando o menor completava a maioridade ou the era concedida a emancipação.

A percepção das fragilidades decorrentes deste sistema proteccionista, a par dos novos valores em matéria de infância e juventude declarados em diversos Tratados e Convenções Internacionais que Portugal fora ratificando (sobretudo a partir de meados do séc. XX), impôs a elaboração de um novo paradigma de intervenção estadual junto das crianças e jovens em perigo e agentes de ilícitos criminais.

É, assim, iniciado o processo de reforma, em $1996^{78}$, com a formação de vários grupos de trabalho e de diversas comissões sob a alçada do Ministério da Justiça e do Trabalho e Solidariedade, que culminará com a aprovação, simultânea, em 1999, da Lei de Protecção de Crianças e Jovens em Perigo ${ }^{79}$ e da Lei Tutelar Educativa ${ }^{80}$.

Visou-se, neste modelo de intervenção, consagrar distintos regimes jurídicos de intervenção estadual junto dos jovens agentes da prática de facto qualificado como crime, com idade compreendida entre os treze e os quinze anos e das crianças e jovens em situação de perigo, com idade inferior a dezoito anos.

"Referia nesse sentido ELIANA GERSÃo, As novas leis de protecção de crianças e jovens em perigo e de tutela educativa - Uma reforma adequada aos dias de hoje, in "Revista Infância e Juventude, 2 (2000), p. 13, como a maior parte das infracções dos jovens pertencentes às classes mais elevadas da sociedade não chegavam a ser participadas pelas autoridades, ou não tinham "consequências sensíveis, por se considerar que a intervenção do tribunal era desnecessária", originando uma verdadeira "criminalização da miséria".

${ }^{78} 0$ processo de reforma foi impulsionado pelo Ministro da Justiça, José Vera Jardim, com a Resolução do Conselho de Ministros no 193/97, de 3 de Outubro, tendo depois sido acompanhado pelo Secretário de Estado, José Luís Lopes da Mota, e pelo Ministro do Trabalho e da Solidariedade Social, Eduardo Ferro Rodrigues, e visou ainda a revisão do regime penal especial para jovens adultos e do instituto da adopção. Cf. ELIANA GERSÃo, As novas leis de protecção de crianças e jovens em perigo e de tutela educativaE, cit., p. 9, nota de rodapé 1; e ALFREDO CASTANHEIRA NEVES, $A$ intervenção do advogado no âmbito do direito dos menores. Alterações legislativas num contexto global de reforma, in "Revista Infância e Juventude", 4 (2000), p. 40.

${ }^{79}$ Aprovada pela Lei $147 / 99$, de 1 de Setembro.

${ }^{80}$ Aprovada pelo Dec.-Lei n ${ }^{0}$ 166/99, de 14 de Setembro. Recorde-se como ambos os citados diplomas legais entraram em vigor a 1 de Setembro de 2001, tendo revogados os arst. $1^{\circ}$ a $145^{\circ}$ da O.T.M.
No primeiro caso, as crianças e jovens agentes de infracções criminais ficariam sujeitas à disciplina prevista na L.T.E., na medida em que o seu cir cunstancialismo exigisse uma intervenção tutelar educativa para o direito e a "sua inserção de forma digna e responsável na vida em comunidade", por se revelarem incapazes de respeitar as regras fundamentais de convivência social. Na verdade, a legitimidade da ingerência do Estado junto do menor e da sua família [art. $2^{0}, n^{0} 1$ da L.T.E.] passa a depender não só do facto de este ter ofendido bens jurídicos fundamentais da sociedade, por se ter feito prova de que havia praticado factos subsumíveis a um tipo legal de crime, mas sobre tudo por aquele revelar necessidade de ser corrigido e educado para o direito.

Diversamente, ao ser sinalizada uma situação de menor em perigo, a legitimidade da intervenção protectora do Estado, passa a ficar dependente de aquela se revelar absolutamente necessária a garantir o seu bem estar e desenvolvimento integral e a promoção dos seus direitos fundamentais, por os seus progenitores, representante legal, ou guardião de facto, se mostrar incapaz de o fazer ou por ser ele o causador desse perigo. Neste caso, a intervenção de protecção efectuar-se-ia no âmbito do preceituado na L.P.C.J.P., diploma este cujos principais traços caracterizadores procuraremos destacar de seguida.

\section{A LEI DE PROTECÇÃO DE CRIANÇAS E JOVENS EM PERIGO}

\subsection{OBJECTIVOS E ÂMBITO DE APLICACC̃̃O}

0 regime jurídico em vigor em matéria de protecção da infância e juventude assenta na ideia nuclear de uma responsabilidade repartida entre o Estado e a sociedade no sentido de assegurar o bem-estar e normal desenvolvimento da personalidade de qualquer criança ou jovem.

Tem por finalidade a promoção dos direitos e a protecção das crianças e jovens em situação qualificada de perigo, com idade igual ou inferior a dezoito anos (ou com idade inferior a vinte e um anos se o jovem solicitar a continuação da intervenção iniciada antes de completar os dezoito anos), que residam ou se encontrem em território nacional ${ }^{81}$.

Neste novo enquadramento legal, fixaram-se critérios de legitimidade de intervenção de terceiros na esfera privada de uma criança ou jovem, ficando aquela dependente de os pais (ou o seu representante legal ou de facto), com a sua acção ou omissão, não consentânea com o exercício das funções ineren-

${ }^{81}$ Cf. art. $2^{\circ}$ e $5^{\circ}$, a) da L.P.C.J.P. 
tes ao exercício do poder paternal, colocarem em perigo a segurança, saúde, formação, educação ou desenvolvimento do menor ou não sejam capazes de o remover de modo adequado.

\subsection{ENTIDADES COM LEGITIMIDADE DE INTERVENÇÃO}

Acentua-se a vertente popular e comunitária do sistema de promoção e protecção de crianças e jovens em perigo na L.P.C.J.P., atribuindo-se competência para intervir a entidades locais com competência em matéria de infância e juventude, para além das C.P.C.J. e do tribunal.

Introduziu-se, assim, uma hierarquia ${ }^{82}$ de intervenção, determinando que esta competirá, em primeira instância (e na medida apenas em que não tenha sido possível por cobro à situação de perigo no interior da família), às entidades locais com atribuições em matéria de infância e juventude (como as Escolas, as entidades Policiais, os Hospitais, os Centros Distritais da Segurança Social e as Instituições Particulares de Solidariedade Social), as quais, por se encontrarem mais próximas do menor e da sua família, podem "lançar mão de recursos mais imediatos e eficazes junto da comunidade que é responsável pelo bem-estar das suas crianças e que está na base da prevenção das situações de perigo" 83 (embora só possam intervir se houver acordo entre todos os intervenientes ${ }^{84}$ e não tenham competência para aplicar nenhuma das medidas de protecção vertidas na L.P.C.J.P.).

Num segundo patamar, é conferida legitimidade de actuação às agora designadas Comissões de Protecção de Crianças e Jovens, quando as referidas entidades locais não garantam ao menor uma protecção adequada no âmbito

${ }^{82}$ Encontramos, porém, na lei duas derrogações ao princípio da subsidiariedade, nas quais o legislador permite passar de imediato da intervenção efectuada pelas entidades com competência em matéria de infância e juventude para a intervenção judicial: nas situações de urgência, enunciadas no art. $91^{\circ}$; ou quando os progenitores dão o seu consentimento ou não se oponham a uma futura adopção do menor (visto as comissões não terem competência para aplicar a medida de promoção e protecção de confiança a pessoa seleccionada para adopção ou a instituição com vista a futura adopção, consagrada na alínea g], do $n^{0} 1$ do art. $35^{\circ}$ da L.P.C.J.P.) ${ }^{83}$ Cf. PAULO GUERRA, 0 novo direito das Crianças e Jovens - Um verdadeiro recomeço, in "Revista Infância e Juventude", 3 (2003), p. 63.

${ }^{84} \mathrm{~A}$ intervenção das entidades locais com competência em matéria de infância e juventude fica dependente da verificação dos dois pressupostos enunciados no art. $7^{\circ}$ da L.P.C.J.P: que os pais, representante legal ou guardião de facto do menor concorde expressamente no sentido da intervenção; e não haja oposição do jovem com idade igual ou superior a doze anos (ou com idade inferior, consoante o seu grau de maturidade]. das funções que Ihes assiste e haja acordo no sentido da sua intervenção ${ }^{85}$. As C.P.C.J. mantêm-se como instituições oficiais não judiciárias que actuam, a par dos tribunais e da comunidade, na protecção das crianças e jovens e na promoção dos seus direitos ${ }^{86}$, integrando elementos com formação nas mais diversas áreas da psicologia, saúde, sociologia, pedagogia, direito, serviço social e ainda por cidadãos eleitores com especiais conhecimentos para intervir nesta área do direito e representantes de diversas entidades ou serviços locais ${ }^{87}$.

São introduzidas ainda duas modalidades de funcionamento das C.P.C.J.: uma alargada, composta por um número elevado de membros dos mais diversos sectores, que visa especialmente a "mobilização da comunidade na promoção do respeito pelos direitos da criança" ${ }^{\prime 8}$, desenvolvendo acções de infor-

${ }^{85}$ A competência material das C.P.C.J. encontra-se, igualmente, dependente da verificação cumulativa de três condições prévias: que as entidades com competência em matéria verificação e juventude, no âmbito exclusivo da sua actividade, não tenham conseguido assegurar de forma adequada e suficiente a protecção que a situação de perigo exige [arts. $8^{\circ}$ e $4^{\circ} \mathrm{j}$ ] da L.P.C.J.P.]; que os pais, representante legal ou quem tenha a guarda de facto da criança ou do jovem consintam de forma expressa a intervenção [art. $9^{\circ}$ da L.P.C.J.P.]; e que o jovem com idade igual ou superior a doze anos, ou com idade inferior, quando a sua capacidade e estado de desenvolvimento the permitam compreender o sentido da intervenção, não se oponha [art. $10^{\circ}$ da L.P.C.J.P]. Como salientam. NORBERTO MARTINS, 0 papel do Ministério Público no sistema de protecção e no encaminhamento para a adopção. A lei de protecção de crianças e Jovens me Perigo. Alterações introduzidas pela Lei 31/03, de 22/08, in "Revista do Ministério Público", Ano 26 102 (Abril/şo 2005), p. 58 e HELENA ISABEL DIAS BOLIEIRO e PAULO GUERRA, in A criança e a família - Uma questão de Direitos, Visão prática dos princípios do Direito da Família e das Crianças e Jovens, (Coimbra Editora/Coimbra, 2009), pp. 42 e 43, o consentimento dos progenitores ou tutores do menor não está dependente de forma especial, podendo ser elaborado à parte do processo de promoção e proteç̧ão ou nele incorporado, e deve ser prestado por ambos, mesmo que só um exerça as responsabilidades parentais (salvo se estiver inibido de as exercer), ou por quem vem assumindo continuadamente as funções essenciais próprias de quem tem responsabilidades parentais. Quanto à não oposição do jovem com idade igual ou superior exigida pelo legislador, sublinhava BEATRIZ MARQUES BORGES, in Protecção de Crianças e Jovens em perigo. Comentários e Anotações à Lei no 147/99, de 1 de Setembro (Almedina/Coimbra, 2007), pp. 73-74, que aquela devia ser consignada por escrito, redigida e assinada pelo menor ou lavrada em auto e por aquele assinado (podendo ser lavrada em acta pelo juiz). No caso de a criança ter idade inferior a doze anos, a sua não oposição deveria também ser reduzida a auto ou transcrita em acta, "dela constando os motivos pelos quais se considerou que a oposição foi conscientemente decidida, compreendendo a criança o sentido da intervenção".

${ }^{86} \mathrm{Cf}$. art. $12^{\circ}$ da L.P.C.J.P.

${ }^{87}$ As C.P.C.J. exercem a sua função na área exclusiva do município onde têm sede, todavia, nos municípios com maior número de habitantes, podendo, quando se justifique, ser criada mais do que uma comissão de protecção com competência numa ou mais freguesias [art.15ํ. ${ }^{88}$ CF. ROSA CLEMENTE, O.C., P. 180. 
mação e promoção dos direitos e de prevenção das situações de perigo para a criança e jovem e exercendo importantes funções de acompanhamento e fiscalização da actividade desenvolvida pela comissão restrita ${ }^{89}$; e uma restrita, formada por um número reduzido de elementos com competência exclusiva para sinalizar, acompanhar e intervir, in loco, nas situações de perigo e aplicar as respectivas medidas de promoção e protecção (com excepção da medida prevista $n$ al. g] do art. $35^{\circ}$ ], dentro dos limites previstos na lei ${ }^{90}$.

Por fim, introduz a intervenção judicial no âmbito da protecção da infância e juventude com natureza subsidiária face à actuação das C.P.C.J.P, tipificando as situações em que aquela será legítima ${ }^{91}$, ao mesmo tempo que fez pender

${ }^{89}$ Cf. art. $21^{\circ}$, al. g) e h] da L.P.C.J.P. A comissão, na modalidade alargada, é formada por um extenso conjunto de membros obrigatórios indicados no art. $18^{\circ}$ da L.P.C.J.P.: cinco representantes do município - um representante da Câmara e quatro da Assembleia Municipal; um representante da segurança social; um representante do ministério da educação (um professor com especial interesse e conhecimento na área das crianças e jovens em perigo); um médico (representante dos centros de saúde); um representante das forças de segurança (que passarão a ser dois, se no município existirem duas forças de segurança, a P.S.P. e a G.N.R); um representante das instituições de solidariedade social e outras organizações não governamentais que desenvolvam actividades em meio natural de vida; um representante de instituições das instituições de solidariedade social e outras organizações não governamentais que exerçam actividades em regime de colocação; um representante da associação de pais; um representante das entidades particulares que desenvolvam actividades culturais e recreativas destinadas a crianças ou jovens; um representante das associações de jovens existentes na área ou dos serviços de juventude; e eventuais membros facultativos, cooptados [art. 18º], que tenham formação específica nas áreas de serviço social, psicologia, saúde ou direito.

${ }^{90} \mathrm{~A}$ comissão, na modalidade restrita, é integrada por um número mais reduzido de elementos: cinco no mínimo (sendo obrigatório que seja sempre um número impar), escolhidos entre os membros da comissão alargada, com formação interdisciplinar e interinstitucional, incluindo, sempre que possível, membros com especialização nas áreas do serviço social, psicologia e direito, educação e saúde, os quais intervêm, in loco, junto das criança ou jovens em perigo e das suas famílias.

${ }^{91} \mathrm{Cf}$. arts. $6^{\circ}$ a $12^{\circ}$ da L.P.C.J.P. A intervenção judicial passa, assim, à luz da L.P.C.J.P., a ter natureza residual, tendo lugar apenas nas situações enunciadas nos arts. $11^{\circ}, 38^{\circ}, 92^{\circ} \mathrm{n}^{0} 3$ e $96^{\circ}$ do citado diploma: quando não exista comissão de protecção de crianças e jovens com competência no município ou na freguesia da respectiva área de residência do menor [al. a] do art. $11^{\circ}$ ]; ou quando aquela não tenha legitimidade ou competência para intervir por: a] os pais, representante legal ou quem tenha a guarda de facto da criança ou do jovem não tenha prestado o seu consentimento no sentido da intervenção, por o ter retirado ou incumprido os termos do acordo de promoção e proteç̧ão [al. b] do art. 11 e art. $9^{\circ}$ ]; b] a criança ou o jovem com idade igual ou superior a doze anos, se haver oposto à intervenção (ou com idade inferior se a sua capacidade e estado de desenvolvimento the permitir compreender o sentido da intervenção] [arts. $10^{\circ}$ e $\left.11^{\circ}\right] ;$ c] nas situações de guarda ocasional, ou seja, se a criança se encontrar a sobre qualquer cidadão o dever de participação indirecta de todas as situações que conheçam de crianças ou jovens em perigo, especialmente quando o bem jurídico em perigo seja a vida, a integridade física ou psíquica ou a liberdade daquele [art. $\left.66^{\circ}, \mathrm{n}^{0} 2\right]^{92}$.

\subsection{PRINCÍPIOS FUNDAMENTAIS}

Ao abrigo da L.P.C.J.P., a intervenção, de base estadual ou comunitária, junto das crianças e jovens e do seu núcleo familiar, passa a ser norteada por um conjunto de princípios fundamentais enunciados no art $4^{\circ}$ do citado diploma.

Para além de voltar a destacar o Princípio do interesse superior da criança e do jovem ${ }^{93}$, como princípio prevalente que deve orientar a actuação das entidades decisoras (sem prejuízo da consideração que for devida a outros interesses legítimos no âmbito da pluralidade dos interesses presentes no caso concreto], enuncia outros que se traduzem em verdadeiras garantias proces suais reconhecidas às crianças ou jovens sujeitos a intervenção protectora (e seus pais, tutores ou guardiães de facto), como o direito à informação, à audição obrigatória e participação ${ }^{94}$, procurando envolvê-los no processo de-

viver com uma pessoa que não detém o poder paternal, nem a sua aguarda legal ou de facto, esta se opuser à intervenção da comissão, enquanto tenta localizar e obter os consentimentos referidos na alínea anterior [art. $9^{\circ}$ ]; d] se a comissão concluir dever ser consentimentos medida de promoção e protecção de confiança a pessoa seleccionada para adopção ou a instituição com vista a futura adopção, prevista na alínea g) do art. $35^{\circ}$, a qual, nos termos do preceituado no art. $38^{\circ}$, só pode ser aplicada pelo juízo; e] se o juiz tiver ordenado a apensação do processo administrativo noutro judicial, nos termos do art. $81^{\circ}, n^{0} 2$ e 3 , por entender que existe ou pode existir incompatibilidade das respectivas medide sequência de procedimento de urgência, nos termos didas ou decisoes [art. $11^{\circ}, g$ g] ] f] e na referir que a intervencão judicil pode de protu a in nã de protecção não obtenha a disponibilidade dos meios necessários para aplicar ou executar a medida que considere adequada, nomeadamente por oposição át $\left.11^{\circ}, d\right]$ ], quando não tenha conseguido aplicar uma medida de promoção e protecção no prazo de seis meses após a sinalização da situação [arts. $11^{\circ}$, e] e $105^{\circ}, n^{\circ} 2$ ], requerendo o M.P., o representante legal do menor ou a própria criança a intervenção judicial; ou considere o M. P. a sua decisão ilegal ou inadequada [art. $11^{\circ}, \mathrm{f}$ )]. Veja-se nesse sentido, o Ac. da Relaça o M. P. a boa no 9237/2006-6, de 16/11/2006; e o Ac. da Relação de Coimtido, o Ac. da Relação de Lis22/05/2007, disponíveis em www.dgsi.pt.

${ }^{92}$ Cf. art. $66^{\circ}, n^{0} 2$ da L.P.C.J.P. A igual obrigação vinculou as entidades policiais, as quais devem informar as C.P.C.J. de todas as situações de crianças em perigo de que tenham tido conhecimento no exercício das suas funções [art $64^{\circ}$, 101]. Vide aind qEATRZ BORGES, o.c., p. 232.

${ }^{93} \mathrm{Cf}$. al. a) do art. $4^{\circ}$ da L.PC J.P.

${ }^{94}$ Cf. al. h] e i) do art. $4^{\circ}$ da L.P.C.J.P. 
cisório relativo às questões e decisões que lhes digam respeito, embora, como esclarece José Manuel Pais, ${ }^{95}$ o seu grau de envolvimento deva ser sempre "progressivo, de acordo com a crescente capacidade da criança para tomar decisões, ou nelas participar".

Simultaneamente salienta-se, ainda, que se deverá privilegiar a protecção da criança ou o jovem no seio do seu meio natural de vida, respeitando a sua privacidade $^{96}$, e assegurando que os seus pais assumam os seus deveres para com ele ${ }^{97}$ através de uma intervenção precoce, actual e mínima ${ }^{98}$ das entidades competentes.

\subsection{MEDIDAS DE PROMOÇÃO E PROTECÇÃO}

Contrariamente ao regime que vigorava na O.T.M. (onde encontrávamos uma cláusula meramente exemplificativa das medidas de protecção e educação], no actual regime da L.P.C.J.P., o legislador optou por enunciar uma lista cerrada de medidas de promoção e protecção passíveis de ser aplicadas a crianças e jovens em perigo.

Essas medidas, enunciadas no art. $35^{\circ}$ da citada lei, encontrando-se escalonadas em função do maior impacto na vida da criança ou do jovem e do facto de poderem ser executadas ou não no seu meio natural de vida ${ }^{99}$, têm

${ }^{95}$ Cf. JOSÉ MANUEL PAIS, Direito à Participação das crianças - Um conto à procura dos seus autores, in "Revista Infância e Juventude", 1 [2005], p. 16.

${ }^{96} \mathrm{Cf}$. al. b] do art. $4^{0}$ da L.P.C.J.P.

${ }^{97}$ (f. al. f) e g) do art. $4^{\circ}$ da L.P.C.J.P. Salienta, assim, o Ac. da Relação de Coimbra, $n^{0} 1337 / 05$ 8TBVNO.C1, 13/02/2007, disponível em www.dgsi.pt, que o princípio da prevalência da família "pressupõe não só que exista essa família mas, e sobretudo, que exista ambiente familiar que permita a integração do menor no seu seio. A família terá de ser mais do que uma rede de vínculos genéticos ou biológicos, devendo comportar em si também toda uma reunião ou feixe de afectos, ou seja, sem a existência de uma envolvência afectiva não poderá falar-se de uma verdadeira família". Exige-se que se possa vislumbrar, in casu, a possibilidade de a família reen contrar o seu equilíbrio em tempo útil: "as crianças não podem estar ao serviço da recuperação dos pais, os pais é que têm que dispor das condições afectivas e éticas para promoverem o de senvolvimento harmonioso dos seus filhos", devidamente apoiadas pelos serviços e entidades competentes".

\section{${ }^{98}$ Cf. al. c), d) e e) do art. $4^{\circ}$ da L.P.C.J.P.}

${ }^{99}$ Só recentemente, em 2008, foram promulgados os diplomas que procederam à regulamen tação das medidas de promoção e protecção de execução em meio natural de vida da criança ou do jovem (de apoio junto dos pais, apoio junto de outro familiar, confiança a pessoa idónea e apoio para a autonomia de vida] e a medida de acolhimento familiar, com a publicação, respec tivamente, do Dec-Lei $n^{0} 12 / 2008$, de 17 de Janeiro, e do Dec-Lei n 11/2008, de 17 de Janeiro. Todas as medidas enunciadas na L.P.C.J.P. têm um carácter transitório, devendo durar pelo por finalidade garantir-Ihe a satisfação das suas necessidades básicas e de todas as condições necessárias ao seu bom e harmonioso desenvolvimento da sua personalidade, e promover os seus direitos fundamentais, económicos, socais e culturais, assegurando-Ihe um espaço de intervenção na sua vida e na comunidade em geral.

Entre as medidas a cumprir no meio natural de vida da criança ou do jovem encontramos: o apoio junto dos pais ; o apoio junto de outro familiar; confiança a pessoa idónea; e o apoio para autonomia de vida. Já as medidas que pressupõem um corte com o seu meio natural consistem: no acolhimento familiar; no acolhimento em instituição; e na confiança a pessoa seleccionada para adopção ou a instituição com vista a futura adopção $0^{100}$.

No momento de seleccionar a medida a aplicar em cada caso, a entidade decisora deverá dar prevalência a uma medida de promoção e protecção que evite a retirada da criança ou do jovem dos seus pais, ou, subsidiariamente confiá-la a um terceiro com quem a criança já estabelecera vínculos recíprocos de afectividade, em detrimento das medidas de colocação, familiar ou institucional, na medida em que, as primeiras, por não provocarem um corte abrupto com a realidade quotidiana e com as entidades afectivas de referência, Ihe são menos gravosas ${ }^{101}$ (salvo quando não se revelem idóneas e adequadas a satisfazer as finalidades supra enunciadas], surgindo a medida de acolhimento institucional como medida de último recurso ${ }^{102}$.

tempo necessário a pôr fim à situação de perigo a que se encontre exposta a criança ou jovem, fixando o legislador prazos máximos da sua duração, com excepção em relação às medidas de colocação. 0 legislador distingue as medidas definitivas excepção em relação às medidas de proteç̧ão ou por decisão judicial) das medidas provisórias, as quais podem ser aplicadas em duas situações: a] nas situações de emergência, que apresentem uma gravidade especial que exige intervenção imediata (mesmo que não se tenha atentado contra a vida ou integridade física da criança e haja consentimento dos pais no sentido da intervencão, daí não se integridade ficom a situação de urgência referida no

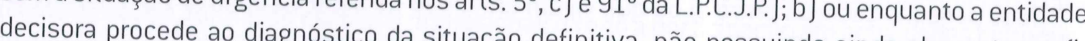
cientes nos autos para proferir uma decisão definitiva [art. $37^{\circ}$ da L.P.C.J.P.].

${ }^{100}$ Embora o legislador tenha qualificado esta medida, quando aplicada na modalidade de confiança a pessoa seleccionada para adopção como medida a executar em meio natural de vida da criança, veio, posteriormente, a excluí-la (e bem) desse rol de medidas no Dec.-Lei n 12/2008, de 17/01. Veja-se nesse mesmo sentido BEATRIZ MARQUES BORGES, o.c., pp.148-149. ${ }^{101} \mathrm{Cf}$. art. $38^{\circ}$ da L.P.C.J.P.

${ }^{102}$ Esta ideia encontra expressão legal no princípio da prevalência da família, plasmado no artº $4^{\circ}$, g) da L.P.C.J.P., e no Pr. 46 dos Princípios orientadores de Riade que consagra a medida de institucionalização como medida de último recurso e nos arts. $5^{\circ}, 7^{\circ}, 9^{\circ}$ e $27^{\circ}$ da Convenção dos Direitos da Criança de 1989. 
As medidas de promoção e protecção podem ser aplicadas mediante decisão negociada, que integra o acordo de promoção e protecção ${ }^{103}$, em processo administrativo ou judicial, ou por resolução judicial ${ }^{104}$, com excepção da medida de confiança a pessoa seleccionada para adopção ou a instituição com vista a futura adopção, que apenas pode ser aplicada judicialmente.

As medidas de execução em meio natural de vida do menor têm como objectivo principal proporcionar ao menor "condições adequadas ao seu desenvolvimento integral, através de apoio psicopedagógico e social e, quando necessário, de apoio económico. ${ }^{105 ",}$ com excepção da medida de apoio para a autonomia de vida, a qual, para além de ter a sua esfera de acção limitada aos jovens com mais de quinze anos ou a com idade inferior se tiverem entretanto sido mães, só pode ser aplicada quando se entenda aconselhável proporcionar ao jovem apoio económico, acompanhamento psicopedagógico e social e formação que Ihe permita, progressivamente, conquistar a sua autonomia.

Quanto à medida de acolhimento familiar, traduz-se esta na confiança de uma criança ou do jovem a uma pessoa singular ou a uma família ${ }^{106}$ habilitada para o efeito, a qual lhe deverá prestar os cuidados adequados às suas necessidades e bem estar e a educação necessária ao seu desenvolvimento integral, em substituição da família natural, quando esta não disponha de condições ${ }^{10 ?}$.

Diversamente, a medida de confiança a pessoa seleccionada para a adopção ou a instituição com vista a futura adopção, introduzida na alínea g] do art. $35^{\circ}$ da L.P.C.J.P. em $2003^{108}$, assume duas formas distintas de execu-

${ }^{103}$ No acordo devem constar as cláusulas obrigatórias, enunciadas nos artigos $56^{\circ}$ e $57^{\circ}$ da L.P.C.J.P., sob pena de este poder ser anulado, o qual deve ser incorporado no processo de promoção e protecção. Cf. BEATRIZ MARQUES BORGES, o.c., p. 161.

${ }^{104}$ Cf. arts. $21^{\circ}$, al. f), $36^{\circ}, 113^{\circ}$ e $121^{\circ}$ da L.P.C.J.P.

${ }^{105} \mathrm{Cf}$. art. $3^{\circ}$ do Dec.-Lei n. ${ }^{0} 12 / 2008$, de 17 de Janeiro

${ }^{106}$ Duas pessoas casadas entre si ou que vivam em união de facto ou parentes que vivam em comunhão de mesa e habitação.

${ }^{107} \mathrm{Cf}$. art. $46^{\circ}$ da L.P.C.J.P. Previu o legislador a possibilidade de constituição de famílias de acoIhimento em lar familiar ou em lar profissional, residindo a sua distinção no facto de nestas últimas não existirem laços de parentesco, matrimoniais ou união de facto entre os seus membros, sendo, sim, formadas por duas ou mais pessoas com formação técnica adequada [art.470 da L.P.C.J.P.; inexistindo, até à presente data, este tipo de famílias de acolhimento). Por outro lado, o acolhimento familiar, quanto à sua duração, apresenta duas modalidades: de curta duração, aplicável quando é previsível o retorno do menor à sua família biológica num prazo não superior a seis meses; e prolongado, quando as circunstâncias do menor não permitam vislumbrar a possibilidade do seu retorno à sua família natural num prazo inferior a seis meses.

${ }^{108}$ Com a aprovação da Lei n ${ }^{0}$ 31/2003, de 22 de Agosto. ção, consoante a criança seja colocada sob a guarda de candidato seleccionado para a adopção, pelo competente organismo de segurança social ${ }^{109}$, caso em que a medida substitui o processo de confiança administrativo e judicial prévio à instauração do processo de adopção; ou sob a guarda de uma instituição com vista à futura adopção (sendo executada em moldes idênticos ao acolhimento em instituição ${ }^{110}$ ).

Por fim, embora sempre como medida de último recurso, pode ser adoptada a medida de acolhimento em instituição que consiste na colocação do menor num estabelecimento "que disponha de instalações e equipamento de acolhimento permanente, e de uma equipa técnica que Ihes garantam os cuidados adequados às suas necessidades e Ihes proporcionem condições que permitam a sua educação, bem-estar e desenvolvimento integral"111.

\section{NOTAS FINAIS}

Decorrido pouco mais de um século desde a publicação da primeira lei especializada em matéria de infância e juventude, em Portugal, são inequívocos os avanços legais ocorridos nesta área do direito.

${ }^{109}$ Nos termos do art. $1979^{\circ}$ do C.C., o candidato poderá ser um casal (constituído por pessoas com vínculo matrimonial e de sexo diferente) ou uma pessoa singular.

${ }^{110} \mathrm{Cf}$. art. $38^{\circ}$-A da L.P.C.J.P.

${ }^{111} \mathrm{Cf}$. art. $49^{\circ}$ da L.P.C.J.P. 0 legislador, no art. $58^{\circ}$ da L.P.C.J.P., enunciou os direitos que devem ser especialmente reconhecidos a todas as criança ou jovens institucionalizados (e incorporados no regulamento de cada instituição], tais como: o direito a ter visitas e a manter contactos regulares, em condições de privacidade, com a família e com as pessoas com quem tenham especial relação afectiva, sem prejuízo das limitações impostas por decisão jum quem tenham missão; a poder contactar, com garantia de confidencialidade, a comissão de protecção, o M.P., o juiz e o seu advogado; a receber uma educação adequada ao seu pleno desenvolvimento e cuidados de saúde, formação escolar e profissional; direito a participação em actividades culturais desportivas. e recreativas; a usufruir de um espaço de privacidade e de um ha condução da sua vida pessoal adequados à sua correspondência); a receber dinheiro de bolso; e a não ser transferido da instituição, salvo quando essa decisão corresponda ao seu interesse. No âmbito do regime vertido na L.P.C.J.P. odas as instituições de acolhimento devem funcionar em regime aberto e ser organizadas em unidades de modo a favorecerem uma "relação afectiva do time aberto e ser organizadas em

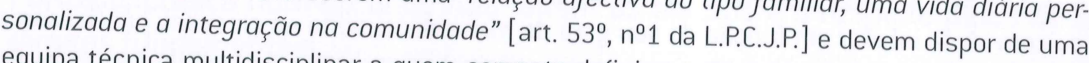
quipa técnica multidisciplinar a quem compete definir e executar o projecto de promoção e protecção de cada menor [art. $54^{\circ}, n^{0} 1$ da L.P.C.J.P.]. Por sua vez, os princípios básicos que devem nortear a vida e organização dos lares de infância e juventude foram enunciados no art. $2^{\circ}$ do Dec.-Lei $n^{0} 2 / 86$, de 2 de Janeiro. 
Cotejados os dispositivos da L.P.C.J.P., podemos concluir tratar-se de um regime que, de uma forma geral, se apresenta sistematicamente coerente e que, materialmente, incorpora os principais valores e princípios proclamados na Convenção dos Direitos da Crianças de 1989.

Entre as notas positivas que se Ihe podem apontar destaque-se, em primeiro lugar, o facto de, na actual jurisdição de menores, se distinguir o tipo de intervenção dirigida às crianças em perigo e aos jovens que incorrem na prática de factos qualificados como crimes pela lei penal, afastando-se a óptica estritamente proteccionista que percepcionava estes últimos como mera vítimas da sociedade, passando a ser responsabilizados pelos seus actos na estrita medida em que necessitem de serem educados para o direito.

Por outro lado, neste novo enquadramento jurídico, a criança e o jovem surgem como verdadeiros actores sociais, titulares de um amplo conjunto de direitos fundamentais e com uma palavra a dizer sobre todas as questões que interfiram com a sua vida, em função da sua idade e do grau de maturidade ${ }^{112}$, tendo direito (assim como aos seus pais, representante legal ou quem tenha a sua guarda de facto], entre o mais, a requerer diligências, oferecer meios de prova, exercer o contraditório em todas as fases do processo e a solicitar a nomeação de advogado ${ }^{113}$.

Reforça-se, ainda, a preferência por um tipo de intervenção não judicia junto dos menores em situação de perigo e das suas famílias, introduzindo-se uma hierarquia de intervenção entre as entidades competentes e critérios legitimadores da sua actuação (em respeito pelo art. $36^{\circ}, n^{0} 5$ e 6 da C.R.P.).

Estipulando que a intervenção junto de uma criança ou jovem em perigo deve efectivar-se em tempo útil, ser proporcional e mínima [art. $4^{\circ}, \mathrm{c}$ ] e d), da L.P.C.J.P.], estende-se a responsabilidade pela sinalização e extinção de qualquer situação de perigo às entidades locais, creches, escolas, centros de saúde, associações recreativas, etc., por se encontrarem mais próximas daqueles e das suas famílias (embora não possam aplicar nenhuma das medidas de protecção enunciadas na lei).

Quanto às comissões de protecção, com vista a ultrapassar algumas das críticas que haviam sido apontadas ao seu trabalho, designadamente que este

1120 direito à participação encontra-se patente em diversos dispositivos legais da L.P.C.J.P impondo-se a audição obrigatória da criança ou jovem com idade igual ou superior a doze anos ou com idade inferior em função do seu grau de maturidade, tanto no processo judicial como administrativo, sobre as situações que deram origem à intervenção: na fase de instrução, na conferência para obtenção de acordo, no debate judicial e sempre que seja aplicada, revista ou declarada cessada uma medida de promoção e protecção [arts. $84^{\circ}$ e10 10 da L.P.C.J.P.]

${ }^{113} \mathrm{Cf}$. arts. $103^{\circ}$ e $104^{\circ}$ da L.P.C.J.P. se traduzia, na prática, numa ingerência excessiva junto do menor e da sua família, com claro desrespeito pela sua privacidade (ao incluírem um número demasiado alargado de membros), no novo regime legal, o legislador prevê o seu funcionamento segundo duas modalidades distintas, uma alargada e ou tra restrita, e define e delimita a esfera de acção de cada uma, excluindo o M.P. como seu membro integrante.

Simultaneamente, relega-se a intervenção judicial para último plano, identificando-se as situações em que esta passa a ser possível.

Em matéria de medidas de promoção e protecção, enuncia o legislador uma lista cerrada de medidas, determinando que estas, sempre que possível, deverão ser fixadas por decisão negociada (não impositiva) e por entidades não judiciais (passando as medidas de execução em meio natural de vida a ter limites máximo de durabilidade].

Acresce que, com a introdução, em 2003, na alínea g] do art. $35^{\circ}, n^{0} 1$ da L.P.C.J.P., da medida de confiança a pessoa seleccionada para adopção, é agilizado o processo de adopção, tornando-se despiciendo, quando aberto um processo de promoção e protecção a uma criança, o recurso a outro procedimento preliminar à adopção, a confiança judicial ou administrativa.

Refira-se ainda que, à luz da L.P.C.J.P., a entidade decisora, no momento da escolha da medida de promoção e protecção a adoptar, passa a ter de dar preferência a uma que não afaste o menor do seu núcleo familiar ou, não sendo possível, que procure a sua reintegração familiar de um modo saudável e harmonioso, ou, subsidiariamente, promova a sua adopção, só podendo ser aplicado o acolhimento residencial como último recurso.

Mais, impõe-se ao Estado e à comunidade o dever de orientar, apoiar, formar os pais na aquisição de tais competências, devendo-se trabalhar "com a família (mais do que sobre a família)"114, designadamente promovendo programas que dêem oportunidade aos pais de aprenderem as funções e obrigações parentais, sensibilizando-os para "os problemas das crianças e jovens"; e pres tando-Ihes ainda apoio económico.

Não obstante os contribuídos inquestionáveis trazidos pelo novo enquadramento normativo da infância e juventude em situação de desprotecção, ainda há muito a fazer nesta área de modo a assegurar que cada criança, em Portugal, cresça num lar onde não faltem os afectos e o respeito pelos seus direitos fundamentais

${ }^{114}$ Cf. PAULO GUERRA, A nova justiça das crianças e jovens. Três anos depois, "Para onde vais, rio que eu canto?", in "Revista Infância e Juventude", 1 [2004), p. 13. 
0 maior desafio, nesta década e nas seguintes, é tornar exequível os preceitos vertidos na L.P.C.J-P., conseguindo trazer para a prática do dia a dia os seus ensinamentos.

São muitos técnicos que trabalham diariamente nas C.P.C.J., nos tribunais ou noutras entidades colaboradoras, e que dão o seu melhor, para trazer sorrisos aos rostos de muitos meninos e meninas a quem um dia faltou um colo, uma família, um lar. Havendo vontade e empenho, todos podemos contribuir para fazer a diferença. Urge avançar!

\section{PRINCIPAIS ABREVIATURAS}

Ac. - Acórdão

A.R. - Assembleia da República

art. - artigo

C.O.A.S. - Centro de observação e acção social

C.C.- Código Civil

C.R.P. - Constituição da República Portuguesa

C.P.C.J. - Comissões de Protecção de Crianças e Jovens

L.P.I. - Lei da Protecção à Infância

L.P.C.J.P. - Lei de Protecção de Crianças e Jovens em Perigo

L.T.E. - Lei Tutelar Educativa

M.P. - Ministério Público

O.T.M. - Organização Tutelar dos Menores

Pr. - Princípio

S.T.J.- Supremo Tribunal de Justiça

\section{REFERÊNCIAS BIBLIOGRÁFICAS}

AFONSO, Paula, As políticas de protecção às crianças em risco. A aposta na intervenção familiar, in "Revista Intervenção Social", 17/18 (1998), pp. 53-68.

ALBUQUERQUE, Catarina de, Os direitos da criança em Portugal e no mundo globalizado. 0 princípio do interesse superior da criança, in "Corpus lus Gentium Conimbrigae", 3 [2004], pp. 39-63; As Nações Unidas e a protecção das Crianças contra a Violência, in "Revista Infância e Juventude", 2 (2006), pp. 57-74.

ASSIZ, Rui, A Intervenção do Estado no Domínio das Crianças e Jovens em Perigo, in "Scientia luridica", T.L., 289 ( Janeiro/Abril, 2001), pp. 157-186.
BAPTISTA-LOPES, Maria Manuela; DUARTE-FONSECA, António Carlos, Aspectos da relação jurídica entre pais e filhos, in "Revista Infância e Juventude", 4 [1988], pp. 7-25.

BATALHA, Vera Burnay, O Provedor de Justiça na defesa dos direitos das crianças e o papel da linha verde "Recados da criança", in "Revista Infância e Juventude", 1 [2002], pp. 95- 109

BOLIEIRO, Helena Isabel Dias, 0 menor em perigo, a sua protecção e o encaminhamento para a adopção: quando e em que casos?, in "Trabalhos do curso de Pós-Graduação "Protecção de menores - Prof. Doutor F. M. Pereira Coelho" - I, 6, Faculdade de Direito da Universidade de Coimbra. Centro de Direito da Família (Coimbra Editora/Coimbra, 2002), pp. 5-82.

BOLIERO, Helena Isabel Dias e GUERRA, Paulo, in A criança e a família - Uma questão de Direitos, Visão prática dos princípios do Direito da Família e das Crianças e Jovens, (Coimbra Editora/Coimbra, 2009)

BONUMA, João, in Menores abandonados e criminosos (Officinas graphicas da Papelaria União/ Santa Maria, Rio Grande do Sul, 1913]

BORGES, Beatriz Marques, in Protecção de Crianças e Jovens em perigo Comentários Anotações à Lei no 147/99, de 1 de Setembro [Almedina/Coimbra, 2007).

BOTAS, José Luís; PINTO, Feliciano, Integração sócio-profissional de jovens em risco, in "Revista Infância e Juventude", pp. 65- ?2.

CALDEIRA, Maria de Fátima, in Assistência Infantil em Lisboa na $1^{a}$ República (Edições Caleidoscópio/ Casal de Cambra, 2004].

CANOTILHO, J.J. Gomes; MOREIRA, E. Vital, in Constituição da República Portuguesa. Lei do Tribunal Constitucional (Coimbra Editora/ Coimbra, 1998).

CAMPOS, Maria Cecília Monteiro de, 0 serviço social no Centro de Observação e Aç̧ão Social de Coimbra, in "Revista Infância e Juventude", 3 (1985), pp. 7-15

CARM0, Rui do, 0 Ministério Público e as Comissões de Protecção de crianças e Jovens, in "Revista do Ministério Público", Ano 23, 91 (Julho/Setembro, 2002), pp. 135-139.

CARNEIRO, Maria do Rosário Amaro da Costa, in Crianças de risco (Instituto Superior de ciências Sociais e Políticas/ Lisboa, 1997], pp. 551-565.

CARREIRA, João Paulo Ferraz, As situações de perigo e as medidas de protecção, in "Direito Tutelar de menores. 0 sistema em mudança", 5, Faculdade de Direito da Universidade de Coimbra. Centro de Direito da Família. Procuradoria - Geral da República (Coimbra Editora/Coimbra, 2002], pp. 25-3?

CLEMENTE, Rosa Maria, Famílias de transição. Uma resposta possível à criança privada de meio familiar normal, in "Revista Infância e Juventude", 1 (1989), pp. 33-37; Um novo olhar sobre a criança. Um direito novo de promoção de direitos e de protecção, in "Revista Intervenção Social", 17/18 (1998), pp. 19-51; in Respostas sociais e institucionais: recursos disponíveis, Direito Tutelar de menores. 0 sistema em 
mudança, 5, Faculdade de Direito da Universidade de Coimbra, Centro de Direito da Família. Procuradoria - Geral da República (Coimbra Editora/Coimbra, 2002), pp. 47-58; in Inovação e modernidade no direito de menores, A Perspectiva da lei de protecção de crianças e jovens em perigo, 16, Faculdade de Direito da Universidade de Coimbra, Centro de Direito da Família (Coimbra Editora/Coimbra, 2009).

CLUNY, Pedro Augusto Lisboa de, 0 direito tutelar de menores e o problema da sua autonomia, in "Scientia luridica", 10 (1961), pp. 148-163;

COELHO, Pereira; OLIVEIRA, Guilherme de, in Curso de Direito da Família, I, (Coimbra Editora/ Coimbra, 2001), pp. 45-82.

DELGADO, Paulo, Identidade e mudança: princípios, funções e dilemas do acolhimento familiar in "Revista Infância e Juventude", 4 (2003), pp. 9-44.

DUARTE-FONSECA, António Carlos, Assessoria técnica em processo tutelar e argumentacão, in "Revista Infância e Juventude", 1 (2001), pp. 69- 100; Serviços Tutelares de Menores, in "Revista Infância e Juventude", 1 (2003), pp. 21-35

EPIFÂNIO, Rui e FARINHA, António, in Organização Tutelar de Menores. Contributo para uma visão interdisciplinar do direito de menores e de família, [Livraria Almedina/Coimbra, 1992] .

EPIFÂNIO, Rui, Acerca das Comissões de Protecção (Decreto-Lei no 189/91, de 17 de Maio, in "Revista Infância e Juventude", 2 [1993], pp. 9-24.

FERNANDES, Ernesto, Direitos e Responsabilidades. Marcos de referência, in "Revista Intervenção Social, número especial, (1998), pp. 9-56.

FONSECA, António Castro, Crianças e Jovens em risco. Análise de algumas questões actuais, in "Crianças e Jovens em risco. Da investigação à intervenção" (Almedina/Coimbra, 2004], pp. 11- 36

FONSECA, Carla, A protecção das crianças e jovens: factores de legitimação e objectivos, in "Direito Tutelar de Menores. 0 sistema em mudança". Faculdade de Direito da Universidade de Coimbra. Centro de Direito da Família. Procuradoria - Geral da República (Coimbra Editora/Coimbra, 2002), pp. 17-23.

FONSECA, Graça e PEDROSO, João, As comissões de protecção: caminhos a percorrer na promoção da cidadania das crianças e jovens, in "Intervenção Social", 17/18 [1998], pp. 27-51.

GERSÃo, Eliana, Comissões de protecção: uma proposta esquecida?, in "Revista Infância e Juventude", 4 [1977], pp. 7-18; Comissões de protecção: uma proposta esquecida? (Continuação), in "Revista Infância e Juventude", 1 (1978), pp. 7-28; As Comissões de proteç̧ão de menores: uma forma (gorada) de participação popular na administração da justiça, in "Revista Infância e Juventude", 2 (1980), pp. 20-28; 0 Centro de Observação e Acção Social de Coimbra, in "Revista Infância e Juventude", 3 (1984], pp. 16-20; Portugal entre as Armadilhas da "Protecção" e da "Justiça" de
Menores, in "Tribuna de Justiça", 4-5 (1990), pp. 89-103; A reabilitação dos menores em função do risco, in "Revista Infância e Juventude", 3 (1996), pp. 9-14; As novas leis de protecção de crianças e jovens e de tutela educativa - Uma reforma adequada aos dias de hoje, in "Revista Infância e Juventude", 2 (2000), pp. 9-44.

GONÇALVES, Caetano, Os serviços de protecção a menores desamparados e delinquentes em Portugal, in "Boletim do Instituto de Criminologia" (1922 a 1923), pp. 13 - 43.

GONÇALVES, Manuel, Os modelos de intervenção institucional e não institucional no âmbito dos menores e jovens adultos. Breve enquadramento jurídico internacional, in "Revista Infância e Juventude", 1 (1999), pp. 113-131.

GUERRA, Paulo, Os menores e os Tribunais. Sinfonia em dois andamentos, in "Revista Infância e Juventude", 3 (2000), p. 9-25; O novo direito das Crianças e Jovens - Um verdadeiro recomeço, in "Revista Infância e Juventude", 3 (2003), pp. 53-80; A nova justiça das crianças e jovens. Três anos depois, "Para onde vais, rio que eu canto?", in "Revista Infância e Juventude", 1 (2004), pp. 9-39.

JORDÃO, Carlos Alberto Rosa de Carvalho, Menoridade e privação de liberdade no direito tutelar de menores, in "Scientia luridica", 14 (1965), pp. 296-321; Menoridade e privação de liberdade no direito tutelar português, in "Scientia luridica", 16 (1967), pp. 65- 81 e 321-331.

LEANDRO, Armando Gomes, Direito e Direito dos Menores. Síntese da situação em Portugal no domínio civil e no domínio para-penal e penal, in "Revista Infância e Juventude, 1 (1990), pp. 9-24; Família do futuro? Futuro da criançaE, in "Revista Infância e Juventude", 1 (1997), pp. 9-20; A criança na cidade dos homens, in "Revista Infância e Juventude", 1 (1998), pp. 9-18; Protecção dos direitos da criança em Portugal, in "Corpus luris Gentium Conimbrigae", 3 (2004), pp. 101-119, Os direitos das crianças nas instituições, in "Revista Infância e Juventude, 3 [2005], pp. 15-24.

LEANDRO, Armando; EPIFÂNIO, Rui, A criança maltratada. Perspectivas de Intervenção, in "Revista do Ministério Público, Ano 7, 27 (Julho/Setembro, 1986), pp. 191-200.

MARREIROS, Guilhermina, 0 Regime da Tutela dos Direitos dos Menores em Portugal, in "Revista Infância e Juventude" 1 (1999), pp. 9-26; As Comissões de Protecção de Crianças e Jovens. 0 papel das Comissões na Promoção dos Direitos e na Proteç̧ão das Crianças e Jovens, in "Revista Infância e Juventude", 2 (2004), pp. 9-31.

MARTINS, Ernesto Candeias, Menores delinquentes e marginalizados (Evolução da política jurídicopenal e sociopedagógica até à $1^{a}$ República), in "Revista Infância e Juventude", 4 (1998), pp. 67-113; As reformas sociais e a protecção da criança marginalizada (Estudo histórico do Século XIX a meados do século XX], in "Revista Infância e Juventude", 3 [2002], pp. 55-93; A infância desprotegida portuguesa na primeira metade do século XX, in "Revista Infância e Juventude", 4 (2006), pp. 93-130.

MARTINS, Norberto, 0 papel do Ministério Público no sistema de protecção e no encaminhamento 
para a adopção. A lei de protecção de crianças e Jovens me Perigo. Alterações introduzidas pela Lei 31/03, de 22/08, in "Revista do Ministério Público", Ano 26 , 102 (Abril/Junho, 2005), pp. 53 - 66.

MATOS, Raquel; FIGUEIREDO, Bárbara, Maus tratos e negligência à Criança: Ressituação de uma problemática, in "Revista Infância e Juventude", 1 [2001], pp. 121-134.

MONACO, Gustavo Ferraz de Campos, $015^{\circ}$ aniversário da Convenção sobre os Direitos da Criança - contributo para o aprofundamento e implementação do Direito Internacional dos direitos Humanos, in "Revista Infância e Juventude", 4 (2004), pp. 9-33.

NEVES, Alfredo Castanheira, A intervenção do advogado no âmbito do direito dos menores. Alterações legislativas num contexto global de reforma, in "Revista Infância e Juventude", 4 (2000), pp. 39-4?

NUTT, Norman, 0 futuro do sistema da justiça de menores, in "Revista Infância e Juventude", 2 (1990), pp. 29-3?.

OLIVEIRA, Augusto d', in Protecção moral e jurídica à infância (Tipografia do Reformatório Central de Lisboa Padre António de Oliveira/ Lisboa, 1929).

PAIS, José Manuel, Direito à Participação das crianças - Um conto à procura dos seus autores, in "Revista Infância e Juventude", 1 (2005), pp. 9-23.

PEDROSO, João, 0 Ministério Público e o apoio técnico aos tribunais: dois factores de crise ou de sucesso da nova lei de protecção de crianças e jovens em perigo, in "Direito Tutelar de menores. 0 sistema em mudança", 5, Faculdade de Direito da Universidade de Coimbra. Centro de Direito da Família. Procuradoria - Geral da República (Coimbra Editora/Coimbra, 2002), pp. 85-90.

PEDROSO, João; GERSÃO, Eliana (coord.), A Justiça de menores: as crianças entre o risco e o crime, in "Relatório do Observatório Permanente da Justiça Portuguesa" (Centro de Estudos Sociais da Faculdade de Economia da Universidade de Coimbra/Março de 1998).

PEREIRA, Luís de Miranda, Os menores na Justiça - a construção do futuro, in "Revista Infância e Juventude" 1 (1993), pp. 73-81; As Misericórdias e os presos: renovação ou esquecimento, in "Revista Portuguesa de Ciência Criminal", 3 ( 2000), pp. 389-399.

PINTO, António Clemente, in Guia de Procedimentos do processo de promoção e protecção, (Almedina/ Coimbra, 2009).

QUELOZ, Nicolas, Abordagem comunitária e delinquência dos jovens: A justiça de menores à procura da comunidade perdida?, in "Revista Infância e Juventude", 3 [1989], pp. 45-59; Protecção, intervenção e direitos das crianças e dos jovens, in "Revista Infância e Juventude", 4 (1991), pp. 39-59; Fenómenos de dissociação do laço social, comportamentos desviantes dos jovens e intervenções sociais, in "Revista Infância e Juventude", 4 (1994), pp. 9-32.

RAMIÃo, Tomé d'Almeida, in A Adopção - Regime Jurídico Actual, (Quid Júris/Lisboa, 2005); in
Lei de Protecção de Crianças e Jovens em Perigo. Anotada e Comentada (0uid Juris/ Lisboa, 2006].

ROCHA, Maria Dulce, Secretismo do processo tutelar e interesse do menor, in "Revista do Ministério Público", Ano 13, 49 (Janeiro/Março 1992), pp. 131-139.

RODRIGUES, Almiro Simões, Interesse do menor (Contributo para uma definição), in "Revista Infância e Juventude", 1 [1985], pp. 7-41; Direitos da Criança: o legislado e o vivido, in "Revista Infância e Juventude", 3 [1994], pp. 37- 134.

RODRIGUES, Anabela Miranda, Repensar o Direito de menores em Portugal- Utopia ou realidade?, in "Revista Portuguesa de Ciência Criminal", Ano ?, 1 (Coimbra Editora/ Coimbra,1997), pp. 355-386; A reforma do direito dos menores (o caso português), in "Anuário de Justiça de Menores" (Astigi/Sevilha, 2001), pp. 314-339.

RODRIGUES, Felicidade Reis, Intervenção do Instituto de Reinserção Social na protecção dos direitos e interesses dos menores, in "Revista infância e Juventude", 1 (1993), pp. 53-71.

SÁ, Eduardo; SOTTOMAYOR, Maria Clara; ROSINHA, Isabel; CUNHA; Maria João, in Abandono e Adopção (Almedina/Coimbra, 2005).

SANTOS, Beleza dos, Regime Jurídico dos menores delinquentes em Portugal, in "Boletim da Faculdade de Direito da Universidade de Coimbra”, 71-80 (Coimbra Editora/Coimbra, 1926], pp. 142-245.

SALGADO, António Mota, Acerca das Comissões de Protecção a menores, in "Revista do Ministério Público", Ano 2, Vol. ? (1981), pp. 115-135.

SERRA, Eurico, Os tribunais de menores e a sua jurisdição, in "Separata do Boletim do Ministério da Justiça", 103 (1961).

SILVA, Maria Helena Damião, Crianças e jovens a cargo das instituições: riscos reversíveis/ irreversíveis, in "Crianças e Jovens em risco. Da investigação à intervenção" (Almedina/Coimbra, 2004), pp. 83-113

SOARES, Natália Fernandes, Direitos da criança: utopia ou realidade, in "Revista Infância e Juventude", 4 (1979), pp. 101-126; Crianças em risco: passado e presente. Alguns contributos para a compreensão histórico-social da problemática das crianças maltratadas e negligenciadas, in "Revista Infância e Juventude", 1 [1997), pp. 35 - 51.

SOUSA, Maria Teresa Trigo de, Competências das Comissões de Protecção de Menores para a aplicação e revisão de medidas por elas promovidas, in "Revista Infância e Juventude", 3 (1983), pp. 7-19.

TOMÁS, Catarina Almeida, Posso falar? De um direito adquirido a um direito subtraído, in "Revista Infância e Juventude", 2 (2001), pp. 93-106.

VALENTE, Manuel Monteiro Guedes, Os princípios estruturantes da intervenção face aos menores e jovens em perigo: uma viagem pela Lei n $147 / 99$, de 1 de Setembro, in “Revista Infância e Juventude", 2 (2004), pp. 69-99. 